\title{
Oxygenated Cyclohexene Derivatives from the Stem and Root Barks of Uvaria pandensis
}

Gasper Maeda, Pieter J. Gilissen, Anastasia Rudenko, Jelle van der Wal, Catarina Bourgard, Arvind Kumar Gupta, Per Sunnerhagen, Joan J. E. Munissi, Stephen S. Nyandoro,* and Máté Erdélyi*

Cite This: J. Nat. Prod. 2021, 84, 3080-3089

Read Online

ACCESS

Llll Metrics \& More

Article Recommendations

Supporting Information

ABSTRACT: Five new cyclohexene derivatives, dipandensin A and $B(1$ and 2 ) and pandensenols $A-C(3-5)$, and 16 known secondary metabolites (6-21) were isolated from the methanolsoluble extracts of the stem and root barks of Uvaria pandensis. The structures were characterized by NMR spectroscopic and mass spectrometric analyses, and that of 6-methoxyzeylenol (6) was further confirmed by single-crystal X-ray crystallography, which also established its absolute configuration. The isolated metabolites were evaluated for antibacterial activity against the Gram-positive
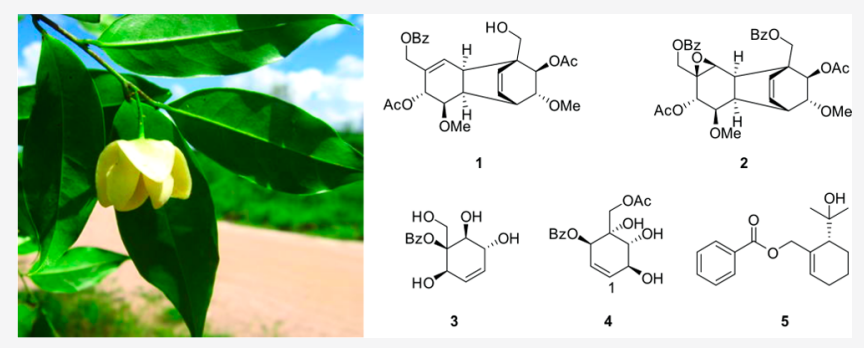
bacteria Bacillus subtilis and Staphylococcus epidermidis and the Gram-negative bacteria Enterococcus raffinosus, Escherichia coli, Paraburkholderia caledonica, Pectobacterium carotovorum, and Pseudomonas putida, as well as for cytotoxicity against the MCF-7 human breast cancer cell line. A mixture of uvaretin (20) and isouvaretin (21) exhibited significant antibacterial activity against B. subtilis $\left(\mathrm{EC}_{50} 8.7 \mu \mathrm{M}\right)$ and $\mathrm{S}$. epidermidis (IC $\left.{ }_{50} 7.9 \mu \mathrm{M}\right)$. ( $8^{\prime} \alpha, 9^{\prime} \beta$-Dihydroxy)-3-farnesylindole (12) showed strong inhibitory activity $\left(\mathrm{EC}_{50} 9.8 \mu \mathrm{M}\right)$ against $B$. subtilis, comparable to the clinical reference ampicillin $\left(\mathrm{EC}_{50} 17.9 \mu \mathrm{M}\right)$. None of the compounds showed relevant cytotoxicity against the MCF-7 human breast cancer cell line.

$\mathrm{T}^{\mathrm{k}}$ he genus Uvaria (Annonaceae) comprises about 168 species distributed throughout Africa and Asia, with additional species continuing to be described. ${ }^{1}$ Members of the genus Uvaria host a vast number of secondary metabolites with varied chemical structures and biological activities. ${ }^{2}$ The phytochemical constituents of the genus Uvaria include flavonoids ${ }^{3}$ and oxygenated cyclohexene derivatives, with the latter being restricted to the genus and its closely related genera within the Uvariae tribe, ${ }^{4-14}$ albeit with very few plant families other than Annonaceae. ${ }^{15-21}$ Thus, oxygenated cyclohexene derivatives have so far been reported from about 20 species of Uvaria ${ }^{4,6-9,14,22-28}$ and other genera of the Uvariae tribe such as Monanthotaxis, ${ }^{10,11,29}$ Ellipeiopsis, ${ }^{12,30}$ Dasymaschalon, ${ }^{31}$ Cleistochlamys, ${ }^{13,32}$ and Artabotrys. ${ }^{33,34}$ These compounds exhibit diverse bioactivities including antiproliferative, ${ }^{15,18,25,35}$ antimalarial, ${ }^{6,9,13}$ antibacterial, ${ }^{32}$ and cytotoxic $^{12,13,31}$ activities.

Our recent findings of the bioactive oxygenated cyclohexene derivatives including their chlorinated counterparts from Cleistochlamys kirkii ${ }^{13}$ and Monathotaxis trichocarpa ${ }^{11}$ inspired a reinvestigation of Uvaria pandensis Verdc., a plant species previously reported to contain similar compounds. ${ }^{6,36}$ The species is used in some parts of Tanzania in traditional medicine to treat stomach disorders and fever. ${ }^{11}$ Reported herein are the isolation and structure determination of five hitherto unreported oxygenated cyclohexene derivatives (15), which were obtained with 16 known compounds (6-21) from the $\mathrm{CH}_{3} \mathrm{OH}$ extracts of stem and root bark samples. The isolated metabolites were evaluated for antibacterial activity against the Gram-positive bacteria Bacillus subtilis and Staphylococcus epidermidis and the Gram-negative bacteria Enterococcus raffinosus, Escherichia coli, Paraburkholderia caledonica, Pectobacterium carotovorum, and Pseudomonas putida. They were also assessed for cytotoxicity against the MCF-7 human breast cancer cell line.

\section{RESULTS AND DISCUSSION}

The separate $\mathrm{CH}_{3} \mathrm{OH}$ extracts of the root and stem barks of $U$. pandensis were subjected to a repeated silica gel chromatographic separation. Further purification on Sephadex LH-20 and by HPLC and recrystallization yielded 21 compounds, of which five (1-5) were new. The structures of the isolated secondary metabolites were elucidated based on their NMR, IR, and UV spectroscopic and mass spectrometric data. The 16 known compounds, 6-methoxyzeylenol (6), ${ }^{5}$ zeylenol (7), ${ }^{35}$ cleistenediol C (8), ${ }^{13}$ cleistenediol F (9), ${ }^{13}$ cherrevenol I

Received: August 31, 2021

Published: November 22, 2021 


\section{Chart 1}

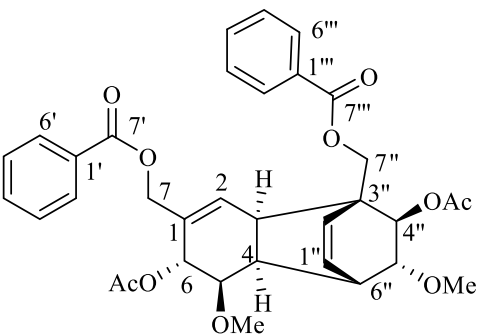

1<smiles>CC(=O)O[C@H]1[C@@H](OC(=O)c2ccccc2)C=C(I)[C@@H](O)[C@H]1O</smiles>

4

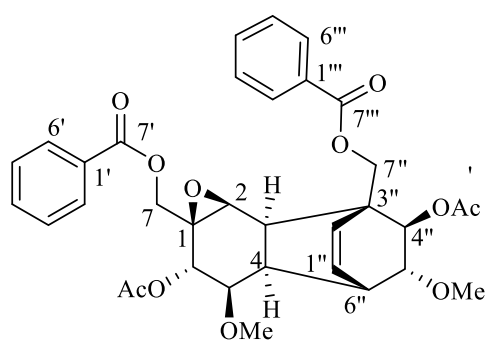

2

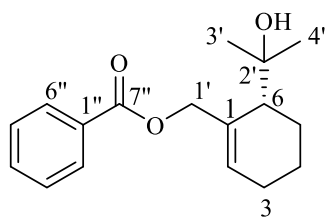<smiles>O=C(OC1(C(O)O)[C@@H](O)[C@H](O)C=C[C@H]1O)c1ccccc1</smiles>

3
(10), ${ }^{9}$ 3-methoxybenzylbenzoate $(\mathbf{1 1}),{ }^{11,37}\left(8^{\prime} \alpha, 9^{\prime} \beta\right.$-dihydroxy)-3-farnesylindole $(12),{ }^{36}\left(6^{\prime}, 7^{\prime}\right.$-dihydro- $8^{\prime} \alpha, 9^{\prime} \beta$-dihydroxy)-3-farnesylindole (13), ${ }^{36}$ zeylenyl-2,6-diacetate (14), ${ }^{35}$ benzoic acid 2,3-diacetoxy-1,6-dihydroxycyclohex-4-enylmethyl ester (15), ${ }^{35}$ lupeol (16), ${ }^{38}$ betulin (17), ${ }^{39}$ a mixture of stigmasterol (18) ${ }^{11}$ and $\beta$-sitosterol (19), ${ }^{11}$ and a mixture of uvaretin $(20)^{40}$ and isouvaretin (21), ${ }^{40}$ were identified by comparison of their spectroscopic data (Supporting Information) to those previously reported in the literature.

Compound 1, $[\alpha]_{\mathrm{D}}^{24}-33\left(c 0.2, \mathrm{CH}_{3} \mathrm{OH}\right)$, was isolated from the $\mathrm{CH}_{3} \mathrm{OH}$ extract of the stem bark of $U$. pandensis as a white solid. The HRESIMS showed a $\left[\mathrm{M}+\mathrm{NH}_{4}\right]^{+}$peak at $\mathrm{m} / z$ 622.2442 (calcd 622.2652 for $\mathrm{C}_{34} \mathrm{H}_{40} \mathrm{NO}_{10}$ ), which in combination with the NMR data (Table 1) indicated 17 double-bond equivalents (DBEs). Additionally, the HRMS showed a base peak at $\mathrm{m} / z 545.1937$ (calcd for $[\mathrm{M}+\mathrm{H}-$ $\mathrm{HOAc}]^{+} 545.2175$ ), indicative of the presence of an acetate group. The UV spectrum exhibited absorption maxima at 208, 229 , and $274 \mathrm{~nm}$, typical for a conjugated $\pi$-system. ${ }^{10}$ The IR spectrum of compound 1 consisted of absorption bands for hydroxy $\left(3520 \mathrm{~cm}^{-1}\right)$, ester carbonyl $\left(1740 \mathrm{~cm}^{-1}\right)$, and double-bond $\left(1635 \mathrm{~cm}^{-1}\right)$ stretches. The ${ }^{1} \mathrm{H}$ and ${ }^{13} \mathrm{C}$ NMR spectroscopic data (Table 1, Figures S1-S2, Supporting Information) of compound 1 showed signals evocative of dimeric polyoxygenated cyclohexene derivatives resembling those previously reported. ${ }^{8,15}$ Thus, the ${ }^{1} \mathrm{H}$ and ${ }^{13} \mathrm{C}$ NMR spectra showed signals at $\delta_{\mathrm{H} / \mathrm{C}} 7.97\left(\mathrm{H}-2^{\prime} / 6^{\prime}\right) / 130.3,7.50(\mathrm{H}-$ $\left.3^{\prime} / 5^{\prime}\right) / 129.5,7.62\left(\mathrm{H}-4^{\prime}\right) / 134.1,131.0$ (C-1), 166.7 (C-7') and $8.04\left(\mathrm{H}-2^{\prime \prime \prime} / 6^{\prime \prime \prime}\right) / 130.4,7.50\left(\mathrm{H}-3^{\prime \prime \prime} / 5^{\prime \prime \prime}\right) / 129.5,7.62$ $\left(\mathrm{H}-4^{\prime \prime \prime}\right) / 134.2$, $131.2\left(\mathrm{C}-1^{\prime \prime \prime}\right), 166.8\left(\mathrm{C}-7^{\prime \prime \prime}\right)$, corresponding to two benzoyloxy units. In addition, the resonances were observed corresponding to two olefinic units $\left[\delta_{\mathrm{H} / \mathrm{C}} 135.2(\mathrm{C}\right.$ 1), $6.02(\mathrm{H}-2) / 129.5,6.28\left(\mathrm{H}-1^{\prime \prime}\right) / 132.6$ and $5.75\left(\mathrm{H}-2^{\prime \prime}\right) /$ $133.0]$, two oxymethylene groups $\left[\delta_{\mathrm{H} / \mathrm{C}} 4.77 / 4.62(\mathrm{H}-7 \mathrm{a} / 7 \mathrm{~b}) /\right.$ $\left.65.3,4.48\left(2 \mathrm{H}, \mathrm{AB}_{\mathrm{q}}, \mathrm{H}-7^{\prime \prime}\right) / 62.3\right]$, two acetoxy groups $\left[\delta_{\mathrm{H} / \mathrm{C}}\right.$ $1.99\left(\mathrm{CH}_{3} \mathrm{COO}-6\right) / 21.1$ and $171.3 ; 1.96\left(\mathrm{CH}_{3} \mathrm{COO}-4^{\prime \prime}\right) / 21.1$ and 170.4], and two methoxy groups $\left[\delta_{\mathrm{H} / \mathrm{C}} 3.37\left(\mathrm{OCH}_{3}-5\right) /\right.$ 57.9 and $\left.3.32\left(\mathrm{OCH}_{3}-5^{\prime \prime}\right) / 57.2\right]$. The COSY and TOCSY spectra (Figures S3 and S6, Supporting Information) showed correlations between $\mathrm{H}-2\left(\delta_{\mathrm{H}} 6.02\right)$ and $\mathrm{H}-3\left(\delta_{\mathrm{H}} 3.04\right), \mathrm{H}-2$ and $\mathrm{H}-6$ (allylic coupling), $\mathrm{H}-3$ and $\mathrm{H}-4\left(\delta_{\mathrm{H}} 3.09\right), \mathrm{H}-4$ and $\mathrm{H}-$ $5\left(\delta_{\mathrm{H}} 3.48\right), \mathrm{H}-3$ and $\mathrm{H}-6$ (long-range-coupling), $\mathrm{H}-5$ and $\mathrm{H}-6$
$\left(\delta_{\mathrm{H}} 5.41\right), \mathrm{H}-1^{\prime \prime}\left(\delta_{\mathrm{H}} 6.28\right)$ and $\mathrm{H}-2^{\prime \prime}\left(\delta_{\mathrm{H}} 5.75\right), \mathrm{H}-1^{\prime \prime}$ and $\mathrm{H}-6^{\prime \prime}$ $\left(\delta_{\mathrm{H}} 3.15\right), \mathrm{H}-4^{\prime \prime}\left(\delta_{\mathrm{H}} 5.09\right)$ and H-5", and H-5" $\left(\delta_{\mathrm{H}} 3.10\right)$ and $\mathrm{H}-6^{\prime \prime}$. These correlations indicated two distinct spin systems corresponding to two cyclohexenyl moieties. The linkage of these units and their substitution patterns were established from HMBC analyses (Table 1, Figure S5, Supporting Information). Thus, the HMBC correlations of $\delta_{\mathrm{H}} 4.62 / 4.77$ $(\mathrm{H}-7 \mathrm{a} / 7 \mathrm{~b})$ to $\mathrm{C}-7^{\prime}\left(\delta_{\mathrm{C}} 166.7\right), \mathrm{C}-1(135.2), \mathrm{C}-2(129.5)$, and C-6 $\left(\delta_{\mathrm{C}} 70.5\right)$ and those of $\delta_{\mathrm{H}} 4.48\left(\mathrm{H}-7^{\prime \prime}\right)$ to C-7"' $\left(\delta_{\mathrm{C}} 166.8\right)$, C-2" $\left(\delta_{\mathrm{C}} 133.0\right), \mathrm{C}-3^{\prime \prime}\left(\delta_{\mathrm{C}} 47.6\right)$, and C-4" $\left(\delta_{\mathrm{C}} 76.5\right)$ indicated the two sets of benzoyloxymethylene units to be attached at C1 and C-3", respectively. The regiochemistry of the two methoxy and two acetate groups was indicated by the HMBC cross-peaks of $\mathrm{CH}_{3} \mathrm{O}-5\left(\delta_{\mathrm{H}} 3.37\right), \mathrm{H}-6\left(\delta_{\mathrm{H}} 5.41\right), \mathrm{H}-4^{\prime \prime}\left(\delta_{\mathrm{H}}\right.$ 5.09), and $\mathrm{CH}_{3} \mathrm{O}-5^{\prime \prime}\left(\delta_{\mathrm{H}} 3.32\right)$ to $\mathrm{C}-5\left(\delta_{\mathrm{C}} 81.4\right)$, OAc-6 $\left(\delta_{\mathrm{C}}\right.$ $171.3)$, OAc- $4^{\prime \prime}\left(\delta_{\mathrm{C}} 170.4\right)$, and C-5" $\left(\delta_{\mathrm{C}} 87.1\right)$, respectively. The HMBC correlations of H-6" $\left(\delta_{\mathrm{H}} 3.15\right)$ to C-3 $\left(\delta_{\mathrm{C}} 40.2\right)$, C-4 $\left(\delta_{\mathrm{C}} 31.1\right)$, and C-5 $\left(\delta_{\mathrm{C}} 81.4\right)$ as well as those of H-4 $\left(\delta_{\mathrm{H}}\right.$ $3.09)$ to $\mathrm{C}-1^{\prime \prime}\left(\delta_{\mathrm{C}} 132.6\right)$ and C-6" $\left(\delta_{\mathrm{C}} 34.1\right)$, and of H-5 $\left(\delta_{\mathrm{H}}\right.$ $3.09)$ to $C-6^{\prime \prime}\left(\delta_{\mathrm{C}} 34.2\right)$ suggested the linkage of the two sets of cyclohexenyl moieties. The NMR and MS data supported by retro-biogenetic analysis led to the conclusion that $\mathbf{1}$ is a dimer of 6-acetoxy-5-methoxy-1,3-dienyl)methylbenzoate moieties and hence the product of the Diels-Alder endo-addition (Figure 1). The fact that $\mathbf{1}$ was isolated as an optically active compound suggests that it is formed in an enzymatic DielsAlder reaction, as the nonenzymatic alternative would be expected to provide a racemic product. $^{41}$

The relative configuration of $\mathbf{1}$ was established based on scalar coupling constants (Table 1) and NOESY correlations (Figure 1 and Figure S7, Supporting Information). Thus, ${ }^{3} J_{\mathrm{H}-4 / 5}(6.5 \mathrm{~Hz})$ and ${ }^{3} \mathrm{~J}_{\mathrm{H}-5 / 6}(9.1 \mathrm{~Hz})$ indicated the cis axialequatorial and the trans diaxial orientation for the corresponding protons, establishing the relative configurations at C-4, C-5, and C-6. Moreover, H-6 exhibited a NOE with H-1", which exhibited also a weak NOE correlation with $\mathrm{H}-5^{\prime \prime}$. The NOE correlation of $\mathrm{CH}_{3} \mathrm{O}-5^{\prime \prime}$ to $\mathrm{H}-4^{\prime \prime}$ was used to establish the relative configurations at C- $4^{\prime \prime}, \mathrm{C}-5^{\prime \prime}$, and C- $6^{\prime \prime}$. The ${ }^{3} \mathrm{~J}_{\mathrm{H}-3 / 4}$ $(9.0 \mathrm{~Hz})$ indicated a cisoid ring junction for the protons at $\mathrm{C}-3$ and C-4. Such a large $J$ value for the bridgehead protons suggested that their dihedral angle is inclined toward an eclipsed orientation. ${ }^{42}$ Based on the above spectroscopic data 
Table 1. NMR Spectroscopic Data ( $500 \mathrm{MHz}, \mathrm{CD}_{3} \mathrm{CN}$ ) for Dipandensin A (1)

\begin{tabular}{|c|c|c|c|c|}
\hline position & $\delta_{\mathrm{C}}$, type & $\delta_{\mathrm{H}}$ & $(\mathrm{J}$ in $\mathrm{Hz})$ & HMBC \\
\hline 1 & 135.2, C & & & \\
\hline 2 & 129.5, CH & 6.02 & $\begin{array}{l}\text { dd }(2.9 \\
2.4)\end{array}$ & $\begin{array}{l}\text { C-1, C-3, C- } 4, C-6, C- \\
\quad 7, C-3^{\prime \prime}\end{array}$ \\
\hline 3 & $40.2, \mathrm{CH}$ & 3.04 & $\begin{array}{l}\text { ddd }(9.0, \\
2.9,2.4)\end{array}$ & $\begin{array}{l}\text { C-1, C-2, C-4, C-5, C- } \\
2^{\prime \prime}, \mathrm{C}-3^{\prime \prime}, \mathrm{C}-4^{\prime \prime}, \mathrm{C}-6^{\prime \prime}\end{array}$ \\
\hline 4 & $31.1, \mathrm{CH}$ & 3.09 & $\begin{array}{l}\mathrm{dd}(9.0 \\
6.5)\end{array}$ & $\begin{array}{l}\text { C-2, C-3, C-5, C-6, C- } \\
1^{\prime \prime}, \mathrm{C}-3^{\prime \prime}, \mathrm{C}-5^{\prime \prime}, \mathrm{C}-6^{\prime \prime}\end{array}$ \\
\hline 5 & $81.4, \mathrm{CH}$ & 3.48 & $\begin{array}{l}\text { dd (9.1, } \\
\quad 6.5)\end{array}$ & $\begin{array}{l}\mathrm{C}-1, \mathrm{C}-3, \mathrm{C}-4, \mathrm{C}-6, \mathrm{C}- \\
\text { 1", }^{\prime \prime} \mathrm{OCH}_{3}-5\end{array}$ \\
\hline $\mathrm{CH}_{3} \mathrm{O}-5$ & $57.9, \mathrm{CH}_{3}$ & 3.37 & s & C-5 \\
\hline 6 & $70.5, \mathrm{CH}$ & 5.41 & $\begin{array}{l}\text { ddd }(9.1 \\
2.4,2.4)\end{array}$ & $\begin{array}{l}\text { C-1, C- } 2, \mathrm{C}-4, \mathrm{C}-5 \text {, } \\
\text { COO-6 }\end{array}$ \\
\hline \multirow[t]{2}{*}{ OAc-6 } & $171.3, \mathrm{OC}=\mathrm{O}$ & & & \\
\hline & 21.1, $\mathrm{CH}_{3}$ & 1.99 & & $\mathrm{COO}-6$ \\
\hline \multirow[t]{2}{*}{7} & 65.3, $\mathrm{CH}_{2}$ & 4.77 & $\mathrm{~d}(12.4)$ & C-1, C-2, C-6, C-7' \\
\hline & & 4.62 & $\mathrm{~d}(12.4)$ & C-1, C-2, C-6, C-7' \\
\hline $1^{\prime}$ & 131.0, C & & & \\
\hline $2^{\prime} / 6^{\prime}$ & $130.3, \mathrm{CH}$ & 7.97 & $\begin{array}{l}\text { dd }(8.3, \\
1.5)\end{array}$ & $\begin{array}{l}\mathrm{C}-1^{\prime}, \mathrm{C}-3^{\prime} / 5^{\prime}, \mathrm{C}-4^{\prime}, \\
\mathrm{C}-7^{\prime}\end{array}$ \\
\hline $3^{\prime} / 5^{\prime}$ & $129.5, \mathrm{CH}$ & 7.50 & $\begin{array}{l}\text { dd }(8.3 \text {, } \\
7.5)\end{array}$ & $\mathrm{C}-1^{\prime}, \mathrm{C}-2^{\prime} / 6^{\prime}, \mathrm{C}-4^{\prime}$ \\
\hline $4^{\prime}$ & 134.1, $\mathrm{CH}$ & 7.62 & $\begin{array}{l}\text { dd }(7.5 \\
1.5)\end{array}$ & $\mathrm{C}-2^{\prime} / 6^{\prime}, \mathrm{C}-3^{\prime} / 5^{\prime}$ \\
\hline $7^{\prime}$ & 166.7, $\mathrm{OC}=\mathrm{O}$ & & & \\
\hline $1^{\prime \prime}$ & 132.6, $\mathrm{CH}$ & 6.28 & $\begin{array}{l}\text { dd }(8.2, \\
6.8)\end{array}$ & $\begin{array}{c}\mathrm{C}-4, \mathrm{C}-2^{\prime \prime}, \mathrm{C}-3^{\prime \prime}, \mathrm{C}-5^{\prime \prime}, \\
\mathrm{C}-6^{\prime \prime}\end{array}$ \\
\hline $2^{\prime \prime}$ & 133.0, $\mathrm{CH}$ & 5.75 & $\mathrm{~d}(8.2)$ & $\mathrm{C}-3^{\prime \prime}, \mathrm{C}-4^{\prime \prime}, \mathrm{C}-6^{\prime \prime}, \mathrm{C}-7^{\prime \prime}$ \\
\hline $3^{\prime \prime}$ & 47.6, C & & & \\
\hline $4^{\prime \prime}$ & $76.5, \mathrm{CO}$ & 5.09 & $\mathrm{~d}(2.9)$ & $\begin{array}{l}\text { C-2", C-3", C-5", C- } \\
\text { 6", C-7", COO-4" }^{\prime \prime}\end{array}$ \\
\hline \multirow[t]{2}{*}{ OAc- $4^{\prime \prime}$} & $170.4, \mathrm{OC}=\mathrm{O}$ & & & \\
\hline & 21.1, $\mathrm{CH}_{3}$ & 1.96 & & $\mathrm{COO}-4^{\prime \prime}$ \\
\hline $5^{\prime \prime}$ & $87.1, \mathrm{CO}$ & 3.10 & $\begin{array}{l}\text { dd }(2.9 \text {, } \\
2.9)\end{array}$ & $\begin{array}{c}\mathrm{C}-1^{\prime \prime}, \mathrm{C}-3^{\prime \prime}, \mathrm{C}-4^{\prime \prime} \\
\mathrm{OCH}_{3}-5^{\prime \prime}, \mathrm{C}-6^{\prime \prime}\end{array}$ \\
\hline $\mathrm{CH}_{3} \mathrm{O}-5^{\prime \prime}$ & $57.2, \mathrm{CH}_{3}$ & 3.32 & s & C-5" \\
\hline $6^{\prime \prime}$ & $34.1, \mathrm{CH}$ & 3.15 & $\begin{array}{l}\text { dd }(6.8 \text {, } \\
2.9)\end{array}$ & $\begin{array}{l}\text { C-3, C-4, C-5, C-1" }{ }^{\prime \prime} \text { C- } \\
2^{\prime \prime}, \text { C- } 4^{\prime \prime}, \text { C-5", }\end{array}$ \\
\hline $7^{\prime \prime}$ & 62.3, $\mathrm{CH}_{2}$ & 4.48 & $\begin{array}{l}\mathrm{AB}_{\mathrm{q}} \\
(12.0)\end{array}$ & $\begin{array}{l}\mathrm{C}-3, \mathrm{C}-2^{\prime \prime}, \mathrm{C}-3^{\prime \prime}, \mathrm{C}-4^{\prime \prime}, \\
\mathrm{C}-7^{\prime \prime \prime}\end{array}$ \\
\hline $1^{\prime \prime \prime}$ & 131.2, C & & & \\
\hline $2^{\prime \prime \prime} / 6^{\prime \prime \prime}$ & $130.4, \mathrm{CH}$ & 8.04 & $\begin{array}{l}\text { dd }(8.4, \\
1.5)\end{array}$ & $\begin{array}{l}\mathrm{C}-1^{\prime \prime \prime}, \mathrm{C}-3^{\prime \prime \prime} / 5^{\prime \prime \prime}, \mathrm{C}-4^{\prime \prime \prime}, \\
\mathrm{C}-7^{\prime \prime \prime}\end{array}$ \\
\hline $3^{\prime \prime \prime} / 5^{\prime \prime \prime}$ & 129.5, CH & 7.50 & $\begin{array}{l}\text { dd }(8.4, \\
7.7)\end{array}$ & $C-1^{\prime \prime \prime}, C-2^{\prime \prime \prime} / 6^{\prime \prime \prime}, C-4^{\prime \prime}$ \\
\hline $4^{\prime \prime \prime}$ & 134.2, $\mathrm{CH}$ & 7.62 & $\begin{array}{c}\mathrm{tt}(7.7 \\
1.5)\end{array}$ & $C-2^{\prime \prime \prime} / 6^{\prime \prime \prime}, C-3^{\prime \prime \prime} / 5^{\prime \prime \prime}$ \\
\hline $7^{\prime \prime \prime}$ & $166.8, \mathrm{OC}=\mathrm{O}$ & & & \\
\hline
\end{tabular}

analysis, the new compound $\mathbf{1}$ (dipandensin A) was characterized as benzoic acid $6 \alpha, 4^{\prime \prime} \beta$-diacetoxy- $3 \alpha$-methylbenzoate-5 $\beta, 5^{\prime \prime} \alpha$-dimethoxytricyclo[6.2.2.0 $\left.0^{3,6 \prime}\right]$ dodeca-2,2" -dien1 -ylmethyl ester.

Compound 2, $[\alpha]_{\mathrm{D}}^{24}-40\left(c 0.2, \mathrm{CH}_{3} \mathrm{OH}\right)$, was isolated from the stem bark $\mathrm{CH}_{3} \mathrm{OH}$ extract as a white solid. Its HRESIMS (Figure S16, Supporting Information) spectrum exhibited a molecular ion $[\mathrm{M}+\mathrm{H}]^{+}$at $\mathrm{m} / z 621.2297$ (calcd 621.2336), corresponding to the molecular formula $\mathrm{C}_{34} \mathrm{H}_{36} \mathrm{O}_{11}$ with 17 DBEs, similar to 1 . The established molecular formula was supported by the NMR data (Table 2). The UV spectrum exhibited absorption maxima at 205 and $230 \mathrm{~nm}$, revealing a conjugated $\pi$-system. ${ }^{10}$ The IR spectrum, again similar to that of 1 , showed absorption bands for hydroxy $\left(3508 \mathrm{~cm}^{-1}\right)$, ester carbonyl $\left(1730 \mathrm{~cm}^{-1}\right)$, and $\mathrm{C}=\mathrm{C}$ bond $\left(1630 \mathrm{~cm}^{-1}\right)$ stretches. The NMR spectroscopic data (Table 2 and Figures S9-S15,
Supporting Information) closely resembled those of dipandensin A (1), with the only difference being saturation at C-1 and C-2. Thus, 2 exhibited a signal at $\delta_{\mathrm{H}} 3.43\left(\delta_{\mathrm{C}} 61.7\right)$ assignable to C-2, compared with $\delta_{\mathrm{H}} 6.02\left(\delta_{\mathrm{C}} 129.5\right)$ for the same position in 1 . In addition, the ${ }^{13} \mathrm{C}$ NMR data (Table 2, Figure S10, Supporting Information) of 2 consisted of a peak at $\delta_{\mathrm{C}} 60.8$ for a tertiary oxygenated carbon, assignable to C-1, instead of $\delta_{\mathrm{C}} 135.2$ observed for $\mathrm{C}-1$ in 1 . The carbon resonances at C-1 (60.8) and C-2 (61.7) were in agreement with a 1,2-epoxide derivative of $\mathbf{1}$. For a 1,2-diol, the carbons would have been expected to resonate at $\sim 70 \mathrm{ppm}$. The oxymethine proton at $\delta_{\mathrm{H}} 3.43(\mathrm{H}-2)$ showed HMBC crosspeaks to C-1 $\left(\delta_{\mathrm{C}} 60.8\right), \mathrm{C}-3\left(\delta_{\mathrm{C}} 38.6\right), \mathrm{C}-4\left(\delta_{\mathrm{C}} 32.8\right), \mathrm{C}-6\left(\delta_{\mathrm{C}}\right.$ $70.3), \mathrm{C}-7\left(\delta_{\mathrm{C}} 63.8\right)$, and C-3" $\left(\delta_{\mathrm{C}} 47.1\right)$, supporting its proposed positioning. The relative configurations at $\mathrm{C}-1$ and C-2 were established based on the NOEs of $\mathrm{H}-2\left(\delta_{\mathrm{H}} 3.43\right)$ with H-3 $\left(\delta_{\mathrm{H}} 2.88\right), \mathrm{H}-4\left(\delta_{\mathrm{H}} 2.91\right), \mathrm{H}-7\left(\delta_{\mathrm{H}} 4.01\right)$, and H-7" $\left(\delta_{\mathrm{H}} 4.64\right)$ (Figure 2 and Figure $S 9$, Supporting Information), indicating these protons to be cofacial. No scalar coupling was measurable between $\mathrm{H}-2$ and $\mathrm{H}-3$, consistent with their dihedral angle being close to $90^{\circ}$. The $J_{\mathrm{H}-3 / 4}(9.1 \mathrm{~Hz})$ suggested their dihedral angle to be inclined toward an eclipsed cis orientation for these protons, whereas the ${ }^{3} J_{\mathrm{H}-5 / 6}(9.9 \mathrm{~Hz})$ indicated their transoid orientation, similar to that in 1 . In compound 1, an allylic coupling of $\mathrm{H}-2$ with $\mathrm{H}-6$ was observed. This coupling was absent for $\mathrm{H}-2$ and $\mathrm{H}-6$ of the saturated cyclohexanyl ring of compound 2 . The relative configurations of the other parts of $\mathbf{2}$ were similar to those of $\mathbf{1}$ as established by analysis of the NOEs (Figure 2 and Figure S9, Supporting Information) and of scalar couplings (Table 2). The HMBC analysis established the linkage of the subunits of $\mathbf{2}$ with all key cross-peaks being similar to $\mathbf{1}$ (Tables 1 and 2). Based on the spectroscopic data obtained, this new compound, dipandensin B (2), was characterized as benzoic acid $4^{\prime \prime} \beta, 6 \alpha$-diacetoxy$1 \beta, 2 \beta$-epoxy-3" $\alpha$-methylbenzoate- $5 \beta, 5^{\prime \prime} \alpha$-dimethoxytricyclo$\left[6.2 \cdot 2 \cdot 0^{4,5}\right]$ dodeca- $1^{\prime \prime}$-en-1-ylmethyl ester. Dimeric polyoxygenated cyclohexene derivatives, such as $\mathbf{1}$ and $\mathbf{2}$, are rare natural products with restricted occurrence in only a few plant species. They have been reported previously from Uvaria cherrevensis ${ }^{8}$ and Kaempferia rotunda (Zingiberaceae). ${ }^{16}$

Compound 3, $[\alpha]_{\mathrm{D}}^{24}-173\left(c 0.2, \mathrm{CH}_{3} \mathrm{OH}\right)$, was isolated from the $\mathrm{CH}_{3} \mathrm{OH}$ extract of the stem bark of $U$. pandensis as a colorless oil. HRESIMS (Figure S24, Supporting Information) indicated a molecular ion $[\mathrm{M}+\mathrm{H}]^{+}$peak at $\mathrm{m} / z 281.1025$ (calcd 281.1025), which along with the NMR data (Table 3) established the molecular formula $\mathrm{C}_{14} \mathrm{H}_{16} \mathrm{O}_{6}$, suggesting 7 DBEs. The IR spectrum showed absorptions at $3330 \mathrm{~cm}^{-1}$ for hydroxy, 2970 and $2944 \mathrm{~cm}^{-1}$ for aliphatic C-H, $1737 \mathrm{~cm}^{-1}$ for ester carbonyl, and $1601 \mathrm{~cm}^{-1}$ for $\mathrm{C}=\mathrm{C}$ stretches. The UV spectrum displayed absorptions at 206 and $229 \mathrm{~nm}$, corresponding to conjugated $\pi$-system. Unlike compounds 1 and 2, the NMR data of compound 3 (Table 3, Figures S17S23 Supporting Information) exhibited signals for only one cyclohexenyl core with benzoyloxy and oxymethylene substituents. The NMR data of 3 consisted of signals corresponding to a tetra-oxygenated cyclohexene skeleton $\left(\delta_{\mathrm{H} / \mathrm{C}} 5.72(\mathrm{H}-1) / 132.8,5.71(\mathrm{H}-2) / 128.2,4.02(\mathrm{H}-3) / 71.2\right.$, $3.65(\mathrm{H}-5) / 74.4,4.18(\mathrm{H}-6) / 71.7$; C-4 (76.4)), a benzoyloxy unit $\left(\delta_{\mathrm{H} / \mathrm{C}} 8.02\left(\mathrm{H}-2^{\prime \prime} / 6^{\prime \prime}\right) / 130.5,7.60\left(\mathrm{H}-4^{\prime \prime}\right) / 132.8,7.48(\mathrm{H}-\right.$ $\left.3^{\prime \prime} / 5^{\prime \prime}\right) / 129.6$, C-1 (134.2), C-7" (169.4)), and an oxymethylene unit $\left(\delta_{\mathrm{H} / \mathrm{C}} 3.82\left(\mathrm{H}-1^{\prime}\right) / 66.2\right)$. Contrary to 1 and 2 and to most polyoxygenated cyclohexenyl derivatives, $^{4-19,21-35,43-45}$ compound 3 lacked an HMBC cross- 

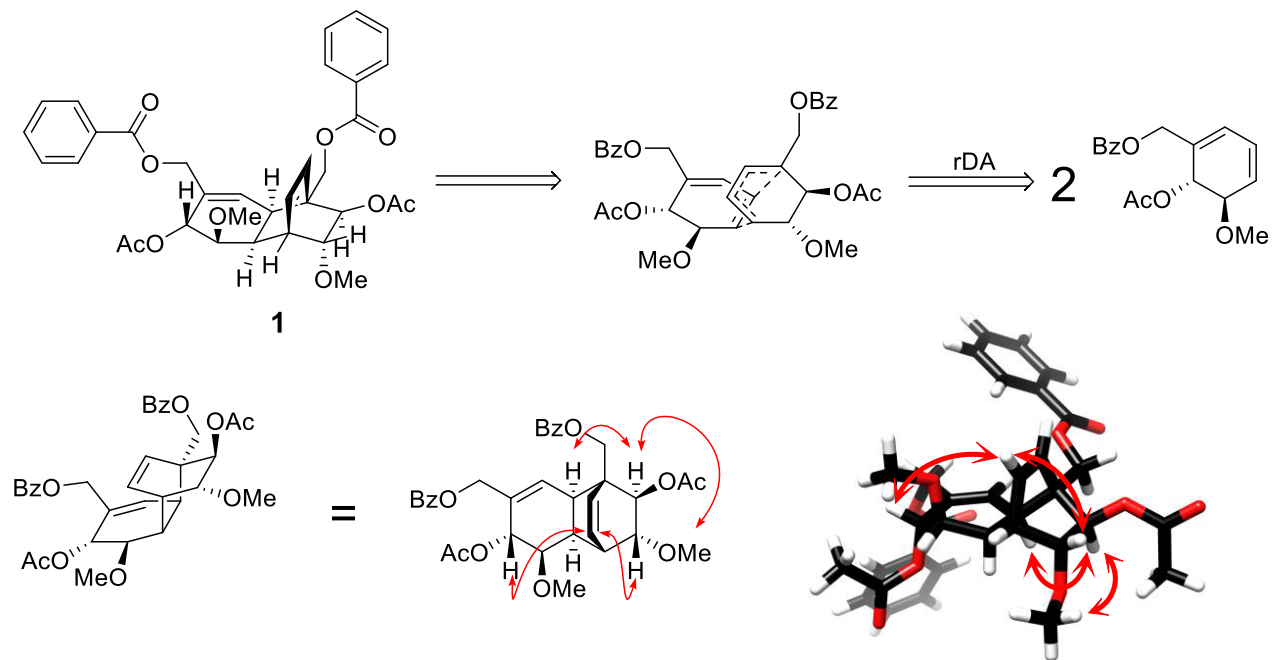

Figure 1. Retro-Diels-Alder analysis and key NOEs (red arrows) of compound $\mathbf{1 .}$

peak (Figure S21, Supporting Information) from the oxymethylene protons $\left(\mathrm{CH}_{2}-1^{\prime} ; \delta_{\mathrm{H}} 3.82, \delta_{\mathrm{C}} 66.2\right)$ to a carbonyl carbon, indicating that the oxymethylene unit is not connected to the benzoyloxy moiety. Thus, the HMBC correlations of $\mathrm{CH}_{2}-1^{\prime}\left(\delta_{\mathrm{H}} 3.82\right)$ to $\mathrm{C}-3\left(\delta_{\mathrm{C}} 71.2\right), \mathrm{C}-4\left(\delta_{\mathrm{C}} 76.4\right)$, and C-5 $\left(\delta_{\mathrm{C}}\right.$ $74.3)$ supported the placement of the oxymethylene functionality at C-4. The benzoyloxy carbonyl did not show HMBC correlations to any protons except $\mathrm{H}-2^{\prime \prime} / \mathrm{H}-6^{\prime \prime}$, indicating that it is attached to the oxycarbon (C-4), making 3 distinctive among polyoxygenated cyclohexene derivatives. The scalar coupling constant ${ }^{3} \mathrm{~J}_{\mathrm{H}-5 / 6}$ of $7.7 \mathrm{~Hz}$ suggested H-5 and H-6 to be trans-diequatorial. In addition, the weak NOEs observed for $\mathrm{H}-5 / \mathrm{H}-6$ and $\mathrm{H}-3 / \mathrm{H}_{-1}{ }^{\prime}$ (Figure 3 and Figure S23, Supporting Information) revealed the relative configurations at C-3, C4, C-5, and C-6. Based on the above spectroscopic data, pandensenol A (3) was characterized as benzoic acid $3 \beta, 5 \beta, 6 \alpha$-trihydroxy- $4 \alpha$-hydroxymethylcyclohex-1-enyl ester.

Compound 4, $[\alpha]^{24}{ }_{\mathrm{D}}+85\left(c 0.3, \mathrm{CH}_{2} \mathrm{Cl}_{2}\right)$, was isolated from the $\mathrm{CH}_{3} \mathrm{OH}$ extract of the stem bark of $U$. pandensis as a white solid. The HRESIMS (Figure S32, Supporting Information) exhibited a molecular ion $[\mathrm{M}+\mathrm{H}]^{+}$peak at $\mathrm{m} / z 323.1191$ (calcd 323.1131), corresponding to the molecular formula $\mathrm{C}_{16} \mathrm{H}_{18} \mathrm{O}_{7}$, which indicated eight DBEs, corresponding to a benzene ring, a cyclohexene ring, and two carbonyl groups (NMR data, Table 4). The UV spectrum showed an absorption maximum at $230 \mathrm{~nm}$, indicating a conjugated $\pi$ system. The IR spectrum exhibited absorption bands for hydroxy $\left(3318 \mathrm{~cm}^{-1}\right)$, aliphatic $\mathrm{C}-\mathrm{H}\left(2943\right.$ and $\left.2832 \mathrm{~cm}^{-1}\right)$, $\mathrm{C}=\mathrm{O}\left(1678 \mathrm{~cm}^{-1}\right)$, and $\mathrm{C}-\mathrm{O}\left(1274 \mathrm{~cm}^{-1}\right)$ stretches. The ${ }^{1} \mathrm{H}$ NMR spectrum (Table 4 and Figure S25, Supporting Information) displayed signals typical of a polyoxygenated cyclohexene derivative. Thus, the ${ }^{1} \mathrm{H}$ NMR spectrum consisted of signals corresponding to protons of a benzoyloxy moiety $\left[\delta_{\mathrm{H}}\right.$ $\left.8.00\left(\mathrm{H}-2^{\prime \prime} / 6^{\prime \prime}\right), 7.50\left(\mathrm{H}-3^{\prime \prime} / 5^{\prime \prime}\right), 7.63\left(\mathrm{H}-4^{\prime \prime}\right)\right]$, an olefinic moiety $\left[\delta_{\mathrm{H}} 5.90(\mathrm{H}-1), 5.76(\mathrm{H}-2)\right]$, three oxymethines $\left[\delta_{\mathrm{H}}\right.$ $5.41(\mathrm{H}-3), 4.18(\mathrm{H}-6), 3.76(\mathrm{H}-5)]$, an oxymethylene $\left(\delta_{\mathrm{H}}\right.$ $4.31)$, and an acetoxy moiety $\left(\delta_{\mathrm{H}} 1.87, \mathrm{CH}_{3}-1^{\prime \prime \prime}\right)$. The corresponding carbon signals were assigned based on HSQC experiments (Table 4, Figure S28, Supporting Information). The COSY and TOCSY correlations (Figures S27 and S30, Supporting Information) for signals at $\delta_{\mathrm{H}} 3.76(\mathrm{H}-5), 4.18(\mathrm{H}-$ 6), $5.90(\mathrm{H}-1), 5.76(\mathrm{H}-2)$, and $5.41(\mathrm{H}-3)$ indicated a continuous spin system, confirming the presence of a cyclohexene core skeleton. The H-2 proton further exhibited allylic coupling with $\mathrm{H}-6$, which in turn coupled with OH-6. Contrary to the previously described polyoxygenated cyclohexene derivatives, the oxymethylene unit $\left(\delta_{\mathrm{H}} 4.31, \delta_{\mathrm{C}} 67.2\right)$ and the acetoxy protons $\left(\delta_{\mathrm{H}} 1.87\right)$ showed mutual $\mathrm{HMBC}$ cross-peaks (Figure S29, Supporting Information) to the C-1 $1^{\prime \prime \prime}$ $\left(\delta_{\mathrm{C}} 171.5\right)$ carbonyl carbon, which supported the presence of an acetoxymethylene unit. The HMBC cross-peaks of $\mathrm{H}-3\left(\delta_{\mathrm{H}}\right.$ 5.41) to C-1 $\left(\delta_{\mathrm{C}} 135.8\right), \mathrm{C}-4\left(\delta_{\mathrm{C}} 74.2\right), \mathrm{C}-5\left(\delta_{\mathrm{C}} 75.3\right), \mathrm{C}-1^{\prime}$ $\left(\delta_{\mathrm{C}} 67.2\right)$, and C-7" $\left(\delta_{\mathrm{C}} 165.9\right)$, together with those of H-1 ${ }^{\prime}$ $\left(\delta_{\mathrm{H}} 4.31\right)$ to C-3 $\left(\delta_{\mathrm{C}} 71.5\right), \mathrm{C}-4\left(\delta_{\mathrm{C}} 74.2\right), \mathrm{C}-5\left(\delta_{\mathrm{C}} 75.3\right)$, and C-1"' $\left(\delta_{\mathrm{C}} 171.5\right)$, corroborated the placement of the benzoyloxy and acetoxymethylene units at C-3 and C-4, respectively. The relative configurations of $\mathrm{H}-5$ and $\mathrm{H}-6$ were established as being trans $\left({ }^{3} J_{\mathrm{H}-5 / 6}=7.6 \mathrm{~Hz}\right)$ in solution. Moreover, the NOE correlations (Figure 4 and Figure S31, Supporting Information) of H-6 $\left(\delta_{\mathrm{H}} 4.18\right)$ to $\mathrm{OH}-4\left(\delta_{\mathrm{H}} 3.42\right)$ and $\mathrm{OH}-5\left(\delta_{\mathrm{H}} 3.34\right)$ and that of $\mathrm{H}-5(3.76)$ to $\mathrm{H}-1^{\prime}\left(\delta_{\mathrm{H}} 4.31\right)$ facilitated assignment of the relative configuration of compound 4 at C-3, C-4, C-5, and C-6. Coincidently, the key NOEs of compounds 4 and $\mathbf{6}$ were similar (Figures 4, S31 and S47, Supporting Information). A single-crystal X-ray structure of compound 6 was obtained (Figure 5), which further supported the configurational assignments of both 4 and 6. Based on the above-mentioned spectroscopic and X-ray crystallographic evidence, this new compound, pandensenol B (4), was characterized as benzoic acid $1 \beta$-acetoxymethyl$4 \alpha, 5 \alpha, 6 \beta$-trihydroxy-cyclohex-1-enyl.

Compound 5, $[\alpha]^{24}+81\left(c 0.2, \mathrm{CH}_{3} \mathrm{OH}\right)$, was isolated from the $\mathrm{CH}_{3} \mathrm{OH}$ extract of the root bark of $U$. pandensis as a white solid. It was assigned the molecular formula $\mathrm{C}_{17} \mathrm{H}_{22} \mathrm{O}_{3}$ based on HRESIMS $\left([\mathrm{M}+\mathrm{H}]^{+} \mathrm{m} / z\right.$ 275.1674, calcd 275.1647; Figure S40, Supporting Information) and NMR data (Table 5) analyses. Its UV spectrum exhibited absorption maxima at 206, 228, and $273 \mathrm{~nm}$ corresponding to a conjugated $\pi$-system. The IR spectrum displayed absorption bands for hydroxy $\left(3439 \mathrm{~cm}^{-1}\right), \mathrm{C}-\mathrm{H}\left(2968\right.$ and $\left.2926 \mathrm{~cm}^{-1}\right)$, $\mathrm{C}=\mathrm{O}\left(1718 \mathrm{~cm}^{-1}\right), \mathrm{C}=\mathrm{C}\left(1601 \mathrm{~cm}^{-1}\right)$, and $\mathrm{C}-\mathrm{O}(1271$ $\mathrm{cm}^{-1}$ ) stretches. Its NMR spectroscopic data (Table 5, Figures S33 and S34, Supporting Information) were to a large extent comparable to those of the polyoxygenated cyclohexene derivatives described above. The ${ }^{1} \mathrm{H}$ and ${ }^{13} \mathrm{C}$ NMR spectroscopic data consisted of signals corresponding to 
Table 2. NMR Spectroscopic Data (500 $\mathrm{MHz}, \mathrm{CD}_{3} \mathrm{CN}$ ) for Dipandensin B (2)

\begin{tabular}{|c|c|c|c|c|}
\hline position & $\delta_{\mathrm{C}}$, type & $\delta_{\mathrm{H}}$ & $\begin{array}{l}(J \text { in } \\
\mathrm{Hz})\end{array}$ & HMBC \\
\hline 1 & $60.8, \mathrm{C}$ & & & \\
\hline 2 & 61.7, $\mathrm{CH}$ & 3.43 & br, s & $\begin{array}{l}\text { C-1, C-3, C-4, C-6, C-7, } \\
\text { C- } 3^{\prime \prime}\end{array}$ \\
\hline 3 & $38.6, \mathrm{CH}$ & 2.88 & $\mathrm{~d}(9.1)$ & $\begin{array}{l}\text { C- } 1, \text { C- } 2, \text { C-4, C-5, C-2", } \\
\text { C- } 3^{\prime \prime}, \text { C-6", C-7" }\end{array}$ \\
\hline 4 & $32.8, \mathrm{CH}$ & 2.91 & $\begin{array}{l}\text { dd }(9.1, \\
5.7)\end{array}$ & $\begin{array}{l}\text { C-2, C-3, C-6, C-1" }{ }^{\prime \prime}, \mathrm{C}- \\
3^{\prime \prime}, \mathrm{C}-5^{\prime \prime}, \mathrm{C}-6^{\prime \prime}\end{array}$ \\
\hline 5 & $77.8, \mathrm{CH}$ & 3.62 & $\begin{array}{l}\text { dd }(9.9, \\
5.7)\end{array}$ & $\begin{array}{l}\mathrm{C}-1, \mathrm{C}-3, \mathrm{C}-4, \mathrm{OCH}_{3}-5 \text {, } \\
\text { C-6, C-6" }\end{array}$ \\
\hline $\mathrm{CH}_{3} \mathrm{O}-5$ & $58.1, \mathrm{CH}_{3}$ & 3.28 & $S$ & $\mathrm{C}-5$ \\
\hline 6 & $70.3, \mathrm{CH}$ & 5.29 & $\mathrm{~d}(9.9)$ & $\begin{array}{l}\text { C- } 1, \text { C- } 2, \text { C- } 4, \text { C-5, C-7, } \\
\text { COO- } 6\end{array}$ \\
\hline \multirow[t]{2}{*}{ OAc-6 } & 171.1, $\mathrm{OC}=\mathrm{O}$ & & & \\
\hline & 21.0, $\mathrm{CH}_{3}$ & 2.07 & s & $\mathrm{COO}-6$ \\
\hline \multirow[t]{2}{*}{7} & 63.8, $\mathrm{CH}_{2}$ & 4.42 & $\mathrm{~d}(11.7)$ & $C-1, C-2, C-6, C-7$ \\
\hline & & 4.01 & $\mathrm{~d}$ & $C-1, C-2, C-6, C-7$ \\
\hline $1^{\prime}$ & $130.9, \mathrm{C}$ & & & \\
\hline $2^{\prime} / 6^{\prime}$ & $130.5, \mathrm{CH}$ & 8.05 & $\mathrm{~m}$ & $\mathrm{C}-1^{\prime}, \mathrm{C}-3^{\prime} / 5^{\prime}, \mathrm{C}-4^{\prime}, \mathrm{C}-7^{\prime}$ \\
\hline $3^{\prime} / 5^{\prime}$ & 129.7, CH & 7.53 & $\mathrm{~m}$ & $\mathrm{C}-1^{\prime}, \mathrm{C}-2^{\prime} / 6^{\prime}, \mathrm{C}-4^{\prime}$ \\
\hline $4^{\prime}$ & $134.4, \mathrm{CH}$ & 7.65 & $\mathrm{~m}$ & $\mathrm{C}-2^{\prime} / 6^{\prime}, \mathrm{C}-3^{\prime} / 5^{\prime}$ \\
\hline $7^{\prime}$ & $166.8, \mathrm{C}=\mathrm{O}$ & & & \\
\hline $1^{\prime \prime}$ & 133.3, $\mathrm{CH}$ & 6.30 & $\begin{array}{l}\text { dd }(8.1 \\
7.5)\end{array}$ & $\begin{array}{l}\mathrm{C}-4, \mathrm{C}-2^{\prime \prime}, \mathrm{C}-3^{\prime \prime}, \mathrm{C}-5^{\prime \prime}, \mathrm{C}- \\
6^{\prime \prime}\end{array}$ \\
\hline $2^{\prime \prime}$ & $132.2, \mathrm{CH}$ & 5.85 & $\mathrm{~d}(8.1)$ & $\mathrm{C}-3^{\prime \prime}, \mathrm{C}-4^{\prime \prime}, \mathrm{C}-6^{\prime \prime}, \mathrm{C}-7^{\prime \prime}$ \\
\hline $3^{\prime \prime}$ & $47.1, \mathrm{C}$ & & & \\
\hline $4^{\prime \prime}$ & 75.7, $\mathrm{CH}$ & 5.07 & $\mathrm{~d}(2.9)$ & $\begin{array}{l}\text { C-5, C-2", C-3", C-5", C- } \\
6^{\prime \prime}, \text { COO- } 4^{\prime \prime}\end{array}$ \\
\hline \multirow[t]{2}{*}{ OAc- $4^{\prime \prime}$} & $170.4, \mathrm{OC}=\mathrm{O}$ & & & \\
\hline & 21.0, $\mathrm{CH}_{3}$ & 1.96 & s & $\mathrm{COO}-4^{\prime \prime}$ \\
\hline $5^{\prime \prime}$ & $87.0, \mathrm{CH}$ & 3.02 & $\begin{array}{l}\text { dd (3.0, } \\
2.9)\end{array}$ & $\begin{array}{l}\mathrm{C}-1^{\prime \prime}, \mathrm{C}-3^{\prime \prime}, \mathrm{C}-4^{\prime \prime}, \mathrm{OCH}_{3}- \\
5^{\prime \prime}, \mathrm{C}-6^{\prime \prime}\end{array}$ \\
\hline $\mathrm{CH}_{3} \mathrm{O}-5^{\prime \prime}$ & 57.0, $\mathrm{CH}_{3}$ & 3.27 & $\mathrm{~s}$ & $\mathrm{C}-5^{\prime \prime}$ \\
\hline $6^{\prime \prime}$ & $33.7, \mathrm{CH}$ & 3.09 & $\begin{array}{l}\text { dd }(7.5 \\
3.0)\end{array}$ & $\begin{array}{l}\text { C-3, C-4, C-5, C-1" }{ }^{\prime \prime}, \mathrm{C}- \\
2^{\prime \prime}, \mathrm{C}-4^{\prime \prime}, \mathrm{C}-5^{\prime \prime}\end{array}$ \\
\hline \multirow[t]{2}{*}{$7^{\prime \prime}$} & 61.6, $\mathrm{CH}_{2}$ & 4.64 & d $(12.2)$ & $\begin{array}{l}\mathrm{C}-3, \mathrm{C}-2^{\prime \prime}, \mathrm{C}-3^{\prime \prime}, \mathrm{C}-4^{\prime \prime}, \mathrm{C}- \\
7^{\prime \prime}\end{array}$ \\
\hline & & 4.52 & $\mathrm{~d}_{(12.2)}$ & $\begin{array}{l}\mathrm{C}-3, \mathrm{C}-2^{\prime \prime}, \mathrm{C}-3^{\prime \prime}, \mathrm{C}-4^{\prime \prime}, \mathrm{C}- \\
7^{\prime \prime}\end{array}$ \\
\hline $1^{\prime \prime \prime}$ & 130.7, C & & & \\
\hline $2^{\prime \prime \prime} / 6^{\prime \prime \prime}$ & $130.4, \mathrm{CH}$ & 8.04 & $\mathrm{~m}$ & $\begin{array}{c}C-1^{\prime \prime \prime}, C-3^{\prime \prime \prime} / 5^{\prime \prime \prime}, C-4^{\prime \prime \prime}, C- \\
7^{\prime \prime \prime}\end{array}$ \\
\hline $3^{\prime \prime \prime} / 5^{\prime \prime \prime}$ & 129.5, $\mathrm{CH}$ & 7.53 & $\mathrm{~m}$ & $C-1^{\prime \prime \prime}, C-2^{\prime \prime \prime} / 6^{\prime \prime \prime}, C-4^{\prime \prime \prime}$ \\
\hline $4^{\prime \prime \prime}$ & 134.2, $\mathrm{CH}$ & 7.65 & $\mathrm{~m}$ & $C-2^{\prime \prime \prime} / 6^{\prime \prime \prime}, C-3^{\prime \prime \prime} / 5^{\prime \prime \prime}$ \\
\hline $7^{\prime \prime \prime}$ & $166.5, \mathrm{C}=\mathrm{O}$ & & & \\
\hline
\end{tabular}

benzoyloxy and oxymethylene units, similar to those observed for compounds 1-4. Furthermore, the ${ }^{1} \mathrm{H}$ NMR data (Table 5) and multiplicity-edited HSQC data (Figure S36, Supporting
Table 3. NMR Spectroscopic Data (500/MHz, $\left.\mathrm{CD}_{3} \mathrm{OD}\right)$ for Pandensenol A (3)

\begin{tabular}{|c|c|c|c|c|}
\hline position & $\delta_{\mathrm{C}}$, type & $\delta_{\mathrm{H}}$ & $(J$ in $\mathrm{Hz})$ & HMBC \\
\hline 1 & $132.8, \mathrm{CH}$ & 5.72 & dd $(10.2,1.3)$ & C-2, C-3, C-5, C-6 \\
\hline 2 & $128.2, \mathrm{CH}$ & 5.71 & dd $(10.2,4.1)$ & C-1, C-3, C-4, C-6 \\
\hline 3 & $71.2, \mathrm{CH}$ & 4.02 & $\mathrm{~d}(4.1)$ & $\begin{array}{l}\text { C-1, C-2, C-4, C-5, C- } \\
1^{\prime}\end{array}$ \\
\hline 4 & 76.4, C & & & \\
\hline 5 & 74.3, $\mathrm{CH}$ & 3.65 & $\mathrm{~d}(7.7)$ & $\begin{array}{l}\mathrm{C}-1, \mathrm{C}-3, \mathrm{C}-4, \mathrm{C}-6, \mathrm{C}- \\
1^{\prime}\end{array}$ \\
\hline 6 & 71.7, $\mathrm{CH}$ & 4.18 & dd $(7.7,1.3)$ & $C-1, C-2, C-4, C-5$ \\
\hline $1^{\prime}$ & 66.2, $\mathrm{CH}_{2}$ & 3.82 & $\mathrm{ABq}(11.5)$ & C-3, C-4, C-5 \\
\hline $2^{\prime}$ & $169.4, \mathrm{C}=\mathrm{O}$ & & & \\
\hline $1^{\prime \prime}$ & 134.2, C & & & \\
\hline $2^{\prime \prime} / 6^{\prime \prime}$ & $130.5, \mathrm{CH}$ & 8.02 & $\mathrm{dd}(7.8,2.1)$ & $\mathrm{C}-1^{\prime \prime}, \mathrm{C}-3^{\prime \prime} / 5^{\prime \prime}, \mathrm{C}-4^{\prime \prime}$ \\
\hline $3^{\prime \prime} / 5^{\prime \prime}$ & 129.6, CH & 7.48 & $\mathrm{dd}(7.8,7.7)$ & $\mathrm{C}-1^{\prime \prime}, \mathrm{C}-2^{\prime \prime} / 6^{\prime \prime}, \mathrm{C}-4^{\prime \prime}$ \\
\hline $4^{\prime \prime}$ & $132.8, \mathrm{CH}$ & 7.60 & tt $(7.7,2.1)$ & $\mathrm{C}-2^{\prime \prime} / 6^{\prime \prime}, \mathrm{C}-3^{\prime \prime} / 5^{\prime \prime}$ \\
\hline
\end{tabular}

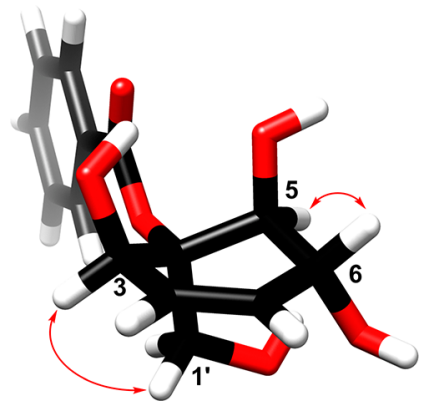

Figure 3. Key NOEs for compound 3, shown as red arrows.

Information) showed signals for an olefinic proton at $\delta_{\mathrm{H} / \mathrm{C}} 5.84$ $(\mathrm{H}-2) / 125.9$, methylene protons at $\delta_{\mathrm{H} / \mathrm{C}} 2.00(\mathrm{H}-3) / 26.4$, two sets of diastereotopic protons at $\delta_{\mathrm{H} / \mathrm{C}} 2.18 / 1.90(\mathrm{H}-4 \mathrm{a} / \mathrm{H}-4 \mathrm{~b}) /$ 26.8 and $\delta_{\mathrm{H} / \mathrm{C}} 1.98 / 1.32(\mathrm{H}-5 \mathrm{a} / \mathrm{H}-5 \mathrm{~b}) / 23.6$, a methine proton at $\delta_{\mathrm{H} / \mathrm{C}} 1.58(\mathrm{H}-6) / 45.0$, and two methyl group protons at $\delta_{\mathrm{H} / \mathrm{C}} 1.20\left(\mathrm{H}-3^{\prime}\right) / 27.1$ and $1.21\left(\mathrm{H}-4^{\prime}\right) / 27.6$. The COSY and TOCSY (Figures S35 and S38, Supporting Information) coupling patterns of these signals suggested the presence of a cyclohexene core structure. Thus, COSY correlations were observed for $\mathrm{H}-2$ and $\mathrm{H}-3, \mathrm{H}-4 \mathrm{~b}$ ( $W$-coupling), and $\mathrm{H}-\mathrm{1}^{\prime}$ (allylic coupling). The $\mathrm{H}-3$ proton further coupled to $\mathrm{H}-4 \mathrm{a} / \mathrm{b}$, which in turn coupled to $\mathrm{H}-5 \mathrm{a} / \mathrm{b}$, while $\mathrm{H}-6$ coupled to $\mathrm{H}-5 \mathrm{a} /$ $\mathrm{b}$ and to $\mathrm{H}-4 \mathrm{~b}$ ( $W$-coupling).

The cyclohexene core structure was confirmed by the ${ }^{3} \mathrm{~J}$ HMBC cross-peaks of H-2 $\left(\delta_{\mathrm{H}} 5.84\right)$ to C-4 $\left(\delta_{\mathrm{C}} 26.6\right)$ and C-6 $\left(\delta_{\mathrm{C}} 45.0\right), \mathrm{H}-3\left(\delta_{\mathrm{H}} 2.00\right)$ to $\mathrm{C}-1\left(\delta_{\mathrm{C}} 130.5\right)$ and C-5 $\left(\delta_{\mathrm{C}} 23.6\right)$, and H-6 $\left(\delta_{\mathrm{H}} 1.58\right)$ to C-2 $\left(\delta_{\mathrm{C}} 125.9\right)$ and C-4 $\left(\delta_{\mathrm{C}} 26.6\right)$ (Table 5 and Figure S37, Supporting Information). In contrast to compounds 1-4, structure 5 lacks oxygenation within the cyclohexene skeleton. Instead, its ${ }^{1} \mathrm{H}$ NMR spectrum exhibited

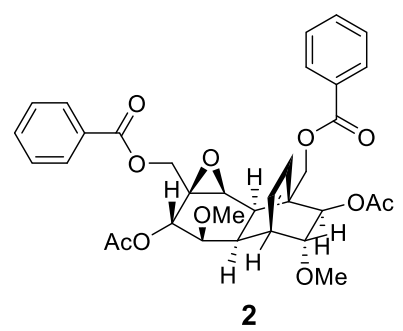

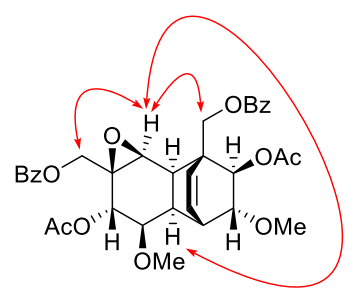

NOEs from $\mathrm{H}-2$

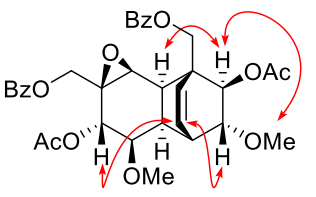

other key NOEs

Figure 2. Key NOEs for compound 2, indicated as red arrows. 
Table 4. NMR Spectroscopic Data (600 MHz, $\left.\mathrm{CD}_{3} \mathrm{CN}\right)$ for Pandensenol B (4)

\begin{tabular}{|c|c|c|c|c|}
\hline position & $\delta_{\mathrm{C}}$, type & $\delta_{\mathrm{H}}$ & $(J$ in $\mathrm{Hz})$ & HMBC \\
\hline 1 & $135.8, \mathrm{CH}$ & 5.90 & $\mathrm{dd}(10.0,2.1)$ & C-2, C-3, C-5, C- 6 \\
\hline 2 & 123.3, $\mathrm{CH}$ & 5.76 & $\begin{array}{l}\text { ddd }(10.0,4.4 \text {, } \\
2.2)\end{array}$ & C-1, C-3, C-4, C-6 \\
\hline 3 & $71.5, \mathrm{CH}$ & 5.41 & $\mathrm{~d}(4.4)$ & $\begin{array}{l}\text { C-1, C-2, C-4, C-5, } \\
\text { C- } 1^{\prime}, \text { C-7" }\end{array}$ \\
\hline 4 & 75.3, C & & & \\
\hline 5 & $74.2, \mathrm{CH}$ & 3.76 & $\mathrm{dd}(7.6,5.7)$ & $\begin{array}{l}\text { C-1, C-3, C-4, C-6, } \\
\text { C- } 1^{\prime}\end{array}$ \\
\hline 6 & $70.7, \mathrm{CH}$ & 4.18 & $\begin{array}{c}\text { dddd }(7.6,6.4 \\
2.2,2.1)\end{array}$ & $\mathrm{C}-1, \mathrm{C}-2, \mathrm{C}-4, \mathrm{C}-5$ \\
\hline $1^{\prime}$ & 67.2, $\mathrm{CH}_{2}$ & 4.31 & $\mathrm{ABq}(11.7)$ & C-3, C-4, C-5, C-1"' \\
\hline $1^{\prime \prime}$ & $130.8, \mathrm{C}$ & & & \\
\hline $2^{\prime \prime} / 6^{\prime \prime}$ & 130.3, CH & 8.00 & $\mathrm{dd}(8.4,1.4)$ & $\begin{array}{l}\mathrm{C}-1^{\prime \prime}, \mathrm{C}-3^{\prime \prime} / 5^{\prime \prime}, \mathrm{C}- \\
4^{\prime \prime}\end{array}$ \\
\hline $3^{\prime \prime} / 5^{\prime \prime}$ & 129.6, CH & 7.50 & dd $(8.4,7.6)$ & $\begin{array}{l}\mathrm{C}-1^{\prime \prime}, \mathrm{C}-2^{\prime \prime} / 6^{\prime \prime}, \mathrm{C}- \\
\end{array}$ \\
\hline $4^{\prime \prime}$ & 134.3, $\mathrm{CH}$ & 7.63 & $\mathrm{tt}(7.6,1.4)$ & $\mathrm{C}-2^{\prime \prime} / 6^{\prime \prime}, \mathrm{C}-3^{\prime \prime} / 5^{\prime \prime}$ \\
\hline $7^{\prime \prime}$ & $165.9, \mathrm{OC}=\mathrm{O}$ & & & \\
\hline OAc- $1^{\prime}$ & $171.5, \mathrm{OC}=\mathrm{O}$ & & & \\
\hline & $20.8, \mathrm{CH}_{3}$ & 1.87 & $\mathrm{~s}$ & $\mathrm{COO}-1^{\prime}$ \\
\hline $\mathrm{OH}-4$ & & 3.42 & $\mathrm{~s}$ & C-3, C-4, C-5, C-1' \\
\hline OH-5 & & 3.34 & $\mathrm{~d}(5.7)$ & C-4, C-5, C-6 \\
\hline OH-6 & & 3.28 & $\mathrm{~d}(6.4)$ & C-1, C-5, C-6 \\
\hline
\end{tabular}

signals at $\delta_{\mathrm{H}} 1.21\left(3 \mathrm{H}, \mathrm{s}, \mathrm{H}-4^{\prime}\right)$ and $1.20\left(3 \mathrm{H}, \mathrm{s}, \mathrm{H}-3^{\prime}\right)$, which were assigned to two methyl groups substituted at the carbinol carbon C-2' $\left(\delta_{\mathrm{C}}\right.$ 72.7). This indicated the presence of an oxygenated isopropyl unit, which is different from the cyclohexene derivatives so far reported in the literature, ${ }^{4-14}$ and was corroborated by the HMBC cross-peaks of H-6 $\left(\delta_{\mathrm{H}}\right.$ $1.58)$ to $\mathrm{C}-2^{\prime}\left(\delta_{\mathrm{C}} 72.7\right)$ and those of the methyl groups $\left(\delta_{\mathrm{H}}\right.$ 1.21 and 1.20$)$ to $\mathrm{C}-6\left(\delta_{\mathrm{C}} 45.0\right)$ and $\mathrm{C}-2^{\prime}\left(\delta_{\mathrm{C}} 72.7\right)$. The position of the benzoyloxymethylene unit was established at $\mathrm{C}$ $1\left(\delta_{\mathrm{C}} 130.5\right)$, based on the cross-peaks of the oxymethylene protons H-1' $\left(\delta_{\mathrm{H}} 4.72\right)$ to $\mathrm{C}-6\left(\delta_{\mathrm{C}} 45.0\right), \mathrm{C}-1\left(\delta_{\mathrm{C}} 130.5\right)$, and C-2 $\left(\delta_{\mathrm{C}} 125.9\right)$. This was supported further by the HMBC cross-peaks of H-2 $\left(\delta_{\mathrm{H}} 5.84\right)$ and $\mathrm{H}-6\left(\delta_{\mathrm{H}} 1.58\right)$ to C-1' $\left(\delta_{\mathrm{C}}\right.$ 68.9). The HMBC correlations of the oxymethylene protons $\left(\delta_{\mathrm{H}} 4.72\right)$ and those of $\mathrm{H}-2^{\prime \prime} / 6^{\prime \prime}\left(\delta_{\mathrm{H}} 8.05\right)$ to C-7" $\left(\delta_{\mathrm{C}} 166.6\right)$ were consistent with the attachment of the methylene unit to the benzoyl unit. Based on the above spectroscopic evidence, the new compound pandensenol $\mathrm{C}$ (5) was characterized as benzoic acid 1-(2'-hydroxy-2'-methylethyl)cyclohex-1-enyl methyl ester.

As similar secondary metabolites were reported to exhibit antibacterial and cytotoxic activities, ${ }^{12,31,32}$ the isolated

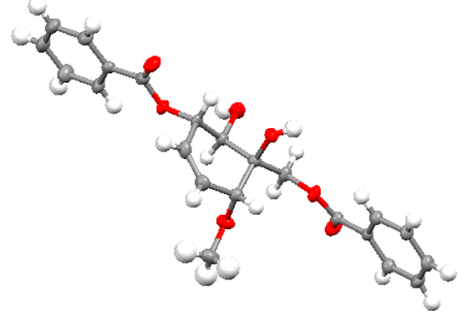

Figure 5. Solid-state structure of 6-methoxyzeylenol (6) shown as thermal ellipsoids with $50 \%$ probability levels.

Table 5. NMR Spectroscopic Data (500 $\left.\mathrm{MHz}, \mathrm{CDCl}_{3}\right)$ for Pandensenol C (5)

\begin{tabular}{|c|c|c|c|c|}
\hline position & $\delta_{\mathrm{C}}$, type & $\delta_{\mathrm{H}}$ & $(J$ in $\mathrm{Hz})$ & $\mathrm{HMBC}$ \\
\hline 1 & 130.5, C & & & \\
\hline 2 & 125.9, $\mathrm{CH}$ & 5.84 & $\mathrm{~m}$ & $\begin{array}{l}\text { C-1, C-3, C-4, C-6, } \\
\text { C-1 } 1^{\prime}\end{array}$ \\
\hline 3 & 26.4, $\mathrm{CH}_{2}$ & 2.20 & $\mathrm{~m}$ & C-1, C-2, C-4, C-5 \\
\hline \multirow[t]{2}{*}{4} & 26.8, $\mathrm{CH}_{2}$ & 1.90 & $\mathrm{~m}$ & C-2, C-3, C-5, C- 6 \\
\hline & & 2.18 & $\mathrm{~m}$ & \\
\hline \multirow[t]{2}{*}{5} & 23.6, $\mathrm{CH}_{2}$ & 1.98 & $\begin{array}{l}\text { ddd }(12.5,5.3 \\
2.3)\end{array}$ & $\begin{array}{l}\text { C-1, C-3, C-4, C-6, } \\
\text { C-2 } 2^{\prime}\end{array}$ \\
\hline & & 1.32 & $\begin{array}{l}\text { ddd }(13.9,12.5 \text {, } \\
5.3)\end{array}$ & $\begin{array}{l}\text { C-1, C-3, C-4, C-6, } \\
\text { C-2' }\end{array}$ \\
\hline 6 & 45.0, $\mathrm{CH}$ & 1.58 & $\begin{array}{l}\text { dddd }(13.9,11.5 \text {, } \\
\quad 4.9,2.5)\end{array}$ & $\begin{array}{l}\text { C- } 1, \text { C- } 4, \text { C- }-5, C-2^{\prime}, \\
\text { C- } 3^{\prime}, 4^{\prime}\end{array}$ \\
\hline $1^{\prime}$ & 68.9, $\mathrm{CH}_{2}$ & 4.72 & $\mathrm{~m}$ & $\mathrm{C}-1, \mathrm{C}-2, \mathrm{C}-6, \mathrm{C}-7^{\prime \prime}$ \\
\hline $2^{\prime}$ & $72.7, \mathrm{C}-\mathrm{O}$ & & & \\
\hline $3^{\prime}$ & 27.1, $\mathrm{CH}_{3}$ & 1.20 & $\mathrm{~s}$ & $\mathrm{C}-2^{\prime}, \mathrm{C}-4^{\prime}$ \\
\hline $4^{\prime}$ & 27.6, $\mathrm{CH}_{3}$ & 1.21 & s & $\mathrm{C}-2^{\prime}, \mathrm{C}-3^{\prime}$ \\
\hline $1^{\prime \prime}$ & 133.1, C & & & \\
\hline $2^{\prime \prime} / 6^{\prime \prime}$ & 129.7, CH & 8.05 & $\mathrm{dd}(8.2,1.4)$ & $\begin{array}{l}\mathrm{C}-3^{\prime \prime} / 5^{\prime \prime}, \mathrm{C}-4^{\prime \prime}, \mathrm{C}- \\
7^{\prime \prime}\end{array}$ \\
\hline $3^{\prime \prime} / 5^{\prime \prime}$ & $128.5, \mathrm{CH}$ & 7.44 & $\mathrm{dd}(8.2,7.4)$ & $\begin{array}{l}\mathrm{C}-2^{\prime \prime} / 6^{\prime \prime}, \mathrm{C}-4^{\prime \prime}, \mathrm{C}- \\
\end{array}$ \\
\hline $4^{\prime \prime}$ & 133.0, CH & 7.56 & tt $(7.4,1.4)$ & $\mathrm{C}-2^{\prime \prime} / 6^{\prime \prime}, \mathrm{C}-3^{\prime \prime} / 5^{\prime \prime}$ \\
\hline $7^{\prime \prime}$ & 166.6, $\mathrm{C}=\mathrm{O}$ & & & \\
\hline
\end{tabular}

compounds were evaluated for their activity against the Gram-positive bacteria Bacillus subtilis and Staphylococcus epidermidis and the Gram-negative bacteria Enterococcus raffinosus, Escherichia coli, Paraburkholderia caledonica, Pectobacterium carotovorum, and Pseudomonas putida as well as for cytotoxicity against MCF-7 human breast cancer cells. The mixture of uvaretin and isouvaretin (20 and 21) obtained exhibited activity against $B$. subtilis $\left(\mathrm{EC}_{50} 8.7 \mu \mathrm{M}\right)$ and $S$. epidermidis $\left(\mathrm{IC}_{50} 7.9 \mu \mathrm{M}\right.$ ), but showed only moderate activity against E. coli $\left(\mathrm{EC}_{50} 1130.8 \mu \mathrm{M}\right)$ and $P$. carotovorum $\left(\mathrm{EC}_{50}\right.$

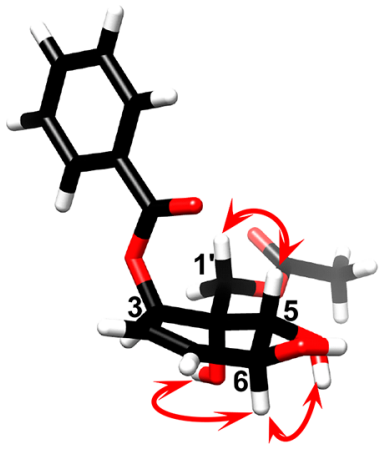

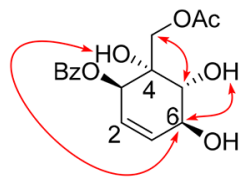

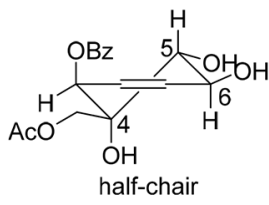

4
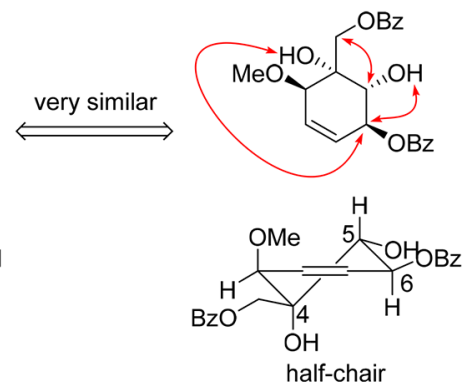

6

Figure 4. Key NOEs of compounds 4 and 6, indicated as red arrows. 
263.1 $\mu \mathrm{M})$. Compound 13 also showed modest activity against B. subtilis, $\mathrm{EC}_{50} 1154.1 \mu \mathrm{M}$, whereas compound 12 gave strong inhibition with an $\mathrm{EC}_{50}$ of $9.8 \mu \mathrm{M}$ (Figure S148, Supporting Information) and was comparable to the known ampicillin antibiotic clinical reference value $\left(\mathrm{EC}_{50} 17.9 \mu \mathrm{M}\right.$, Figure S151, Supporting Information). All other compounds showed no or low activity against the tested bacterial strains ( $\mathrm{MIC}>725$ $\mu \mathrm{M})$ and no relevant cytotoxicity $\left(\mathrm{EC}_{50}>10 \mu \mathrm{M}\right.$ ) (Figure S150, Supporting Information).

In conclusion, 21 natural products including the five new cyclohexene derivatives 1-5 were isolated and characterized from separate $\mathrm{CH}_{3} \mathrm{OH}$ extracts of the stem and root barks of $U$. pandensis. This is the first report of all but compounds $12^{36}$ and $13^{36}$ from this plant. Polyoxygenated cyclohexenes and $C$ benzylated chalcones have restricted occurrence in plants. They are known to be produced by the members of the Uvariae tribe of the family Annonaceae. Hence, their occurrence in U. pandensis is of chemotaxonomic importance, confirming the placement of this plant in the Uvariae taxon. Some of the isolated compounds showed activity against Gram-positive bacteria, along with low to moderate cytotoxicity.

\section{EXPERIMENTAL SECTION}

General Experimental Procedures. Optical rotations were determined using a $341 \mathrm{LC}$ OROT polarimeter $\left(589 \mathrm{~nm}, 20{ }^{\circ} \mathrm{C}\right)$, whereas UV measurements were done using a 264 UV-vis spectrophotometer. A MIR 450FT-IR spectrometer was used to record the IR spectra. NMR spectra were acquired on either a Bruker Avance III HD $600 / 500$ or $400 \mathrm{NMR} \mathrm{MHz}$ spectrometer and were analyzed with the MestReNova (v10.0.0) software. Structural assignments were based on ${ }^{1} \mathrm{H}$ NMR, ${ }^{13} \mathrm{C}$ NMR, COSY, TOCSY, NOESY, HSQC, and HMBC spectra. LC-MS (ESI) spectra were acquired with a PerkinElmer PE SCIEX API 150 EX instrument equipped with a Turbolon spray ion source and a Gemini $5 \mathrm{~mm} \mathrm{RP}$ $\mathrm{C}_{18} 110 \AA$ column, using a gradient of $\mathrm{H}_{2} \mathrm{O}-\mathrm{CH}_{3} \mathrm{CN}$ (80:20 to $20: 80$ ) in the presence of $0.2 \% \mathrm{HCO}_{2} \mathrm{H}$ and a separation time of 8 min. HRESIMS were obtained with a Q-TOF-LC/MS spectrometer with a lock mass ESI source (Stenhagen Analysis Lab AB, Gothenburg, Sweden), using a $2.1 \times 30 \mathrm{~mm} 1.7 \mu \mathrm{m} \mathrm{RP}-\mathrm{C}_{18}$ column and an elution gradient of $\mathrm{H}_{2} \mathrm{O}-\mathrm{CH}_{3} \mathrm{CN}$ (5:95 to 95:5, with $0.2 \%$ $\mathrm{HCO}_{2} \mathrm{H}$ ). Analytical TLC was performed on aluminum plates precoated with silica gel 60 F254 (Merck). After development with an appropriate solvent system, the plates were evaluated under UV light (254 and $366 \mathrm{~nm})$ and then sprayed with 4-anisaldehyde reagent, prepared by mixing $3.5 \mathrm{~mL}$ of 4 -anisaldehyde with $2.5 \mathrm{~mL}$ of concentrated $\mathrm{H}_{2} \mathrm{SO}_{4}, 4 \mathrm{~mL}$ of glacial $\mathrm{HOAc}$, and $90 \mathrm{~mL}$ of $\mathrm{CH}_{3} \mathrm{OH}$. The plates were then heated for the identification of UV-negative compounds and assessment of the color change of the UV-positive spots. Column chromatography was carried out using silica gel 60 (230-400 mesh), and gel filtration was performed over Sephadex LH20 (Pharmacia) suspended in $\mathrm{CH}_{2} \mathrm{Cl}_{2}-\mathrm{CH}_{3} \mathrm{OH}$ (1:1). Preparative HPLC was performed on a Waters $600 \mathrm{E}$ system using Chromulan software (Pikron Ltd.) and an RP-C $\mathrm{C}_{8}$ Kromasil column $(250 \mathrm{~mm} \times 25$ $\mathrm{mm}$ ) with a $\mathrm{H}_{2} \mathrm{O}-\mathrm{CH}_{3} \mathrm{OH}$ gradient (70:30 to $\left.100: 0\right)$ for $20-40 \mathrm{~min}$ at a flow rate of $7 \mathrm{~mL} / \mathrm{min}$.

Plant Material. The root $(230.0 \mathrm{~g})$ and stem $(983.7 \mathrm{~g})$ barks of $U$. pandensis were collected separately from the Mkwagulo and Mtakayo clans' sacred forest graveyards in Fukayosi Village, Bagamoyo District, in Pwani Region, at GPS location 6 $6^{\circ} 4^{\prime} 51.918^{\prime \prime}$ S 38 $40^{\prime} 19.308^{\prime \prime}$ E altitude $78.80 \mathrm{~m}$. The taxonomic identification of the plant species was performed by Mr. F. M. Mbago in the field and confirmed at the Herbarium, Botany Department of the University of Dar es Salaam, where a voucher specimen (FMM-3807) was deposited.

Extraction and Isolation. The stem and root barks of $U$. pandensis were air-dried for 2 weeks and then powdered to obtain 230.0 and $983.7 \mathrm{~g}$ samples, respectively. The ground materials were then soaked in $\mathrm{CH}_{3} \mathrm{OH}$ for $48 \mathrm{~h}$ twice for each of the plant parts. The filtrates were concentrated in vacuo on a rotary evaporator at $40{ }^{\circ} \mathrm{C}$ to obtain $45 \mathrm{~g}$ of root bark and $23.0 \mathrm{~g}$ of stem bark crude extracts.

Gravity column chromatography of the root bark crude extract (45 g) was performed by adsorbing the extract on silica gel followed by gradient elution with solvent systems ranging from 5\% EtOAcisohexane to $10 \% \mathrm{EtOAc}-\mathrm{CH}_{3} \mathrm{OH}$. Altogether 215 fractions of ca. $250 \mathrm{~mL}$ each were collected, then combined to obtain 33 fractions based on TLC analysis. Prior to combining, fraction 165 obtained with $50 \%$ EtOAc-isohexane elution precipitated and was further purified using isohexane to give zeylenol (7, $9.2 \mathrm{mg}$ ). Fraction 79, obtained with $5 \%$ EtOAc-isohexane, precipitated from $\mathrm{CH}_{3} \mathrm{OH}$ to give $17.6 \mathrm{mg}$ of a mixture of stigmasterol (18) and $\beta$-sitosterol (19). Fraction $20(117-131)$ obtained with $50 \% \mathrm{EtOAc}-$ isohexane was subjected to passage over a Sephadex column $\left(1: 1 \mathrm{CH}_{3} \mathrm{OH}-\mathrm{CH}_{2} \mathrm{Cl}_{2}\right)$ to afford 18 fractions, from which subsequent subfractions 1 (5-7), 3 $(9-12)$, and $4(15-16)$ gave cherrevenol I $(10,12.4 \mathrm{mg})$, pandensenol C (5, $6.7 \mathrm{mg})$, and ( $8^{\prime} \alpha, 9^{\prime} \beta$-dihydroxy)-3-farnesylindole $(12,12.1 \mathrm{mg})$, respectively. Fraction $21(132-133)$ obtained with $50 \%$ ethyl acetate-isohexane precipitated from EtOAc-isohexane and crystallized on standing in EtOAc to give 6-methoxyzeylenol (6, $18.5 \mathrm{mg}$ ). The soluble portion of fraction 21 (132-133) was subjected to preparative HPLC utilizing a $\mathrm{H}_{2} \mathrm{O}-\mathrm{CH}_{3} \mathrm{OH}$ eluent system, affording 3-methoxybenzylbenzoate $(11,5.2 \mathrm{mg})$ and $\left(6^{\prime}, 7^{\prime}\right.$ dihydro- $8^{\prime} \alpha, 9^{\prime} \alpha$-dihydroxy)-3-farnesylindole (13, $\left.8.7 \mathrm{mg}\right)$, at 9.45 and 12.46 min retention times, respectively. Fraction 25 (155-167) obtained with 50\% EtOAc-isohexane was subjected to Sephadex column separation utilizing $\mathrm{CH}_{3} \mathrm{OH}-\mathrm{CH}_{2} \mathrm{Cl}_{2}(1: 1)$ as eluent system to afford seven fractions (ca. $2 \mathrm{~mL}$ each). Subfraction 2 contained pandensenol A (3,9.2 $\mathrm{mg})$, while the rest of the subfractions contained complex mixtures of inseparable compounds. Fraction 25 $(142-145)$ was subjected to passage over a Sephadex column eluting with $\mathrm{CH}_{3} \mathrm{OH}-\mathrm{CH}_{2} \mathrm{Cl}_{2}$ (1:1) to afford 12 subfractions of ca. $2 \mathrm{~mL}$ each. Subfractions 5-8 were then subjected to HPLC utilizing a $\mathrm{H}_{2} \mathrm{O}-\mathrm{CH}_{3} \mathrm{OH}$ eluent system to afford cleistenediol C $(5.5 \mathrm{mg}, 8)$ and cleistenediol $\mathrm{F}(3.6 \mathrm{mg}, 9)$ with retention times of 9.88 and 13.43 min, respectively.

The stem bark crude extract $(23.0 \mathrm{~g})$ was adsorbed on silica gel and subjected to gravity column chromatography employing gradient elution ranging from $5 \% \mathrm{EtOAc}$-isohexane to $10 \% \mathrm{CH}_{3} \mathrm{OH}-\mathrm{EtOAc}$, to afford 356 fractions (ca. $200 \mathrm{~mL}$ each). Based on TLC analysis, the fractions were combined to obtain 69 fractions, of which fraction 44 (206-208), eluted with 30-50\% EtOAc-isohexane, was purified further using reversed-phase HPLC, which afforded a mixture (10.3 $\mathrm{mg}$ ) of uvaretin (20) and isouvaretin (21) at a retention time of 13.53 min. Fraction 54 (274-278), obtained with 50-70\% EtOAcisohexane, precipitated in $\mathrm{CH}_{3} \mathrm{OH}$ to give benzoic acid 2,3diacetoxy-1,6-dihydroxycyclohex-4-enyl methyl ester $(15,6.4 \mathrm{mg})$. Fraction 59 (291-294) precipitated in EtOAc to furnish $11.5 \mathrm{mg}$ of lupeol (16). Fraction 47 (246-253), obtained with 50-70\% EtOAcisohexane, was subjected to gel filtration using a Sephadex column $\left(1: 1 \mathrm{CH}_{3} \mathrm{OH}-\mathrm{CH}_{2} \mathrm{Cl}_{2}\right)$ to give 30 subfractions that on TLC analysis were combined to obtain a further nine subfractions. Subfraction 4 (19-20) was subjected to reversed-phase HPLC for further purification, from which at a retention time of 14.29 min zeylenyl2,6-diacetate $(14,5.2 \mathrm{mg})$ was collected. Combined fraction 66 (319-327), obtained with 50-70\% EtOAc-isohexane, was subjected to Sephadex column $\left(1: 1 \mathrm{CH}_{3} \mathrm{OH}-\mathrm{CH}_{2} \mathrm{Cl}_{2}\right)$ purification and then reversed-phase $\mathrm{HPLC}$ utilizing $\mathrm{CH}_{3} \mathrm{OH}-\mathrm{H}_{2} \mathrm{O}$ to give pandensenol A $(3,3.6 \mathrm{mg})$ at a retention time of $11.30 \mathrm{~min}$. Fraction $69(351-356)$, obtained with $50-70 \%$ EtOAc-isohexane, was subjected to separation over a Sephadex column $\left(1: 1 \mathrm{CH}_{3} \mathrm{OH}-\mathrm{CH}_{2} \mathrm{Cl}_{2}\right)$, whereby 35 subfractions of ca. $1 \mathrm{~mL}$ each were collected, which were then combined to obtain 13 subfractions upon TLC analysis. Subfraction 4 precipitated in $\mathrm{CH}_{2} \mathrm{Cl}_{2}$ to give betulin $(17,3.4 \mathrm{mg})$. Subfraction 12 was subjected to reversed-phase HPLC, affording pandensenol B (4, $4.2 \mathrm{mg})$, dipandensin A (1, 4.2 mg), and dipandensin B (2, 3.4 mg) at retention times of $9.48,11.32$, and $14.56 \mathrm{~min}$, respectively. The remaining subfractions resulted into either reisolation of the compounds or inseparable mixtures. 
Dipandensin A (1). White solid; $[\alpha]^{24}-33\left(c 0.2, \mathrm{CH}_{3} \mathrm{OH}\right)$; UV $\left(\mathrm{CH}_{3} \mathrm{OH}\right) \lambda_{\max }(\log \varepsilon) 273$ (3.40), $230(2.37), 205$ (3.24) nm; IR $\nu_{\max } 3520,2973,2940,2915,2824,2325,2120,1740,1722,1635$, $1471,1453,1369,1315,1270,1230,1216 \mathrm{~cm}^{-1} ;{ }^{1} \mathrm{H}$ and ${ }^{13} \mathrm{C}$ NMR data, see Table 1 ; HRESIMS $m / z 622.2652\left[\mathrm{M}+\mathrm{NH}_{4}\right]^{+}$(calcd for $\left.\mathrm{C}_{34} \mathrm{H}_{40} \mathrm{NO}_{10}, 622.2442\right)$.

Dipandensin $B$ (2). White solid; $[\alpha]^{24}{ }_{D}-40\left(c 0.2, \mathrm{CH}_{3} \mathrm{OH}\right)$; UV $\left(\mathrm{CH}_{3} \mathrm{OH}\right) \lambda_{\max }(\log \varepsilon) 274$ (3.43), $230(4.27), 205$ (4.24) nm; IR $\nu_{\max } 3508,2949,2947,2833,2262,1386,1199,1026,833 \mathrm{~cm}^{-1} ;{ }^{1} \mathrm{H}$ and ${ }^{13} \mathrm{C}$ NMR data, see Table 2; HRESIMS $m / z$ 621.2297 $[\mathrm{M}+\mathrm{H}]^{+}$ (calcd for $\mathrm{C}_{34} \mathrm{H}_{37} \mathrm{O}_{11}, 621.2336$ ).

Pandensenol A (3). Colorless oil; $[\alpha]^{24}-173\left(c 0.2, \mathrm{CH}_{3} \mathrm{OH}\right)$; $\mathrm{UV}\left(\mathrm{CH}_{3} \mathrm{OH}\right) \lambda_{\max }(\log \varepsilon) 229(2.33), 206(3.44) \mathrm{nm} ;[\alpha]_{\mathrm{D}}^{24}-173$ (c 0.2, $\left.\mathrm{CH}_{3} \mathrm{OH}\right)$; IR $\nu_{\max } 3330,2970,2944,1737,1634,1601,1561$, $1413,1316,1229,1217,1032 \mathrm{~cm}^{-1}$; ${ }^{1} \mathrm{H}$ and ${ }^{13} \mathrm{C}$ NMR data, see Table 3; HRESIMS $m / z$ 281.1025 $[\mathrm{M}+\mathrm{H}]^{+}$(calcd for $\mathrm{C}_{14} \mathrm{H}_{17} \mathrm{O}_{6}$, 281.1025).

Pandensenol $B$ (4). White solid; $[\alpha]_{\mathrm{D}}^{24}+85\left(c 0.3, \mathrm{CH}_{2} \mathrm{Cl}_{2}\right)$; UV $\left(\mathrm{CH}_{3} \mathrm{OH}\right) \lambda_{\max }(\log \varepsilon) 230(2.48) \mathrm{nm}$; IR $\nu_{\max } 3318,2943,2832$, $1678,1451,1402,1274,1112,1023 \mathrm{~cm}^{-1} ;{ }^{1} \mathrm{H}$ and ${ }^{13} \mathrm{C}$ NMR data, see Table 4; HRESIMS $m / z$ 323.1191 $[\mathrm{M}+\mathrm{H}]^{+}\left(\right.$calcd for $\mathrm{C}_{16} \mathrm{H}_{19} \mathrm{O}_{7}$ 323.1131).

Pandensenol $\mathrm{C}$ (5). White solid; $[\alpha]^{24}{ }_{\mathrm{D}}+81\left(c 0.2, \mathrm{CH}_{3} \mathrm{OH}\right)$; UV $\left(\mathrm{CH}_{3} \mathrm{OH}\right) \lambda_{\max }(\log \varepsilon) 273(2.04), 228(3.01), 206(3.37) \mathrm{nm}$; IR $\nu_{\max } 3439,2968,2926,1718,1601,1584,1451,1367,1314,1271$, 1176, 11069, 1111, 1026, 916, 809, 687, $711 \mathrm{~cm}^{-1}$; ${ }^{1} \mathrm{H}$ and ${ }^{13} \mathrm{C}$ NMR data, see Table 5; HRESIMS $\mathrm{m} / z 275.1674[\mathrm{M}+\mathrm{H}]^{+}$(calcd for $\left.\mathrm{C}_{17} \mathrm{H}_{23} \mathrm{O}_{3}, 275.1647\right)$.

X-ray Diffraction Analysis of 6-Methoxyzeylenol (6). The solid state structure of $\mathbf{6}$ was determined from single crystals of $\mathbf{6}$, obtained by crystallization from EtOAc. Data were collected on a Bruker D8 APEX-II equipped with a CCD camera using Mo $\mathrm{K} \alpha$ radiation $(\lambda=0.71073 \AA)$. Crystals were mounted on a fiber loop and fixated using Fomblin oil. Data reduction was performed with SAINT, ${ }^{46}$ and absorption corrections for the area detector were performed using SADABS. ${ }^{47}$ The structure was solved in the orthorhombic space group $P 2_{1} 2_{1} 2_{1}$ by direct methods and refined by least-squares methods on $F^{2}$ using the SHELX and the OLEX2 software suits. ${ }^{48-50}$ The data were collected at $150(2) \mathrm{K}$. Nonhydrogen atoms were refined anisotropically. Hydrogen atoms were constrained in geometrical positions relative to their parent atoms. A Flack parameter of $0.2(8)$ precluded determination of the absolute structure based on anomalous dispersion. ${ }^{51,52}$ Further details of structure solutions and refinements can be found in the Supporting Information. The X-ray structure data of 6 (CCDC 2105244) have been deposited with the Cambridge Crystallographic Data Centre. Copies of the data can be obtained, free of charge, on application to the Director, CCDC, 12 Union Road, Cambridge CB2 1EZ, UK (fax: + 44-(0)1223-336033 or e-mail: deposit@ccdc.cam.ac.uk).

Antibacterial Assays. The antibacterial activity of the isolated compounds was determined against two Gram-positive bacteria, Bacillus subtilis (NBRC/ATCC \#111470) and Staphylococcus epidermidis (ATCC \#35984) and five Gram-negative bacteria, Escherichia coli MG1655 (CGSC \#6300), Paraburkholderia caledonica (NBRC/ATCC \#102488), Pseudomonas putida (NBRC/ATCC \#100650), Pectobacterium carotovorum (NBRC/ATCC \#3380), and Enterococcus raffinosus (NBRC/ATCC \#100492). The bacteria were cultured as previously described by Mueller and Hinton, and Doyle. Initially, the compounds were dissolved at $10 \mathrm{mg} / \mathrm{mL}$ in $100 \%$ DMSO, then further diluted $30 \times$ in $\mathrm{H}_{2} \mathrm{O}$ and stored at $-20{ }^{\circ} \mathrm{C}$. For in vitro determination of antibacterial activity, a culture of bacterial cells was grown to OD $600_{\mathrm{nm}}=0.5$. The culture was diluted $10 \times$ with prewarmed medium, and the compounds to be tested were added to the culture medium for a final concentration of $30 \mu \mathrm{g} / \mathrm{mL}$, each at 100 $\mu \mathrm{L}$ in a 96-well microtiter plate, then incubated at $37{ }^{\circ} \mathrm{C}$ without agitation for $18 \mathrm{~h}$. To measure cell viability, the resazurin-based assay was used, as described previously. To each well was added $12 \mu \mathrm{L}$ of $10 \times$ alamarBlue solution (resazurin solution, ThermoFisher), and the plate incubated at $37{ }^{\circ} \mathrm{C}$ for $1 \mathrm{~h}$. Next, the fluorescence was measured using a POLARstar Omega microplate-reader from BMG Labtech with the excitation filter set to $544 \mathrm{~nm}$ and the emission filter at 590 $\mathrm{nm}$. Cells exposed to an equivalent concentration of DMSO were used as a negative control. Bleed-through of fluorescence from resorufin between wells in the microtiter plate fluorescence reader was measured and found to be $<1 \%$ between adjacent wells. To check for quenching of fluorescence by any of the investigated compounds, grown bacterial cultures were mixed after $1 \mathrm{~h}$ of incubation with resazurin and the compound of interest at the highest concentration to be assayed, and the measured fluorescence was compared with samples without compound added. All tests of compound activity were performed in three independent replicates. Those compounds where a reduction of fluorescence by at least $50 \%$ relative to the solvent control was observed in any of the bacterial species tested were followed up by additional tests for more accurate determination of the degree of antibacterial activity in terms of minimum inhibitory concentration (MIC). $\mathrm{EC}_{50}$ values, from three independent replicate experiments, using 2-fold dilution intervals were also calculated.

Cytotoxicity Assay. The cytotoxicity levels of the isolated compounds were evaluated against human MCF-7 cells grown in Dulbecco's modified Eagle medium supplemented with $10 \%$ fetal calf serum and kept in exponential growth as previously reported. Before the assay, cells were reseeded into 96-well microtiter plates at a density allowing continued exponential growth and allowed to settle for $24 \mathrm{~h}$. The isolated compounds were added from a stock solution in DMSO, for a final concentration of $0.3 \% \mathrm{v} / \mathrm{v}$ of the solvent in the culture medium. After $24 \mathrm{~h}$ of incubation in the presence of the compound, cell viability was assayed using PrestoBlue Cell Viability Reagent (ThermoFisher) according to the manufacturer's instructions. A Polar Star Omega plate reader (BMG Lab Tech) was used to measure resorufin fluorescence at $544 \mathrm{~nm}$ excitation/590 nm emissions. Survival was expressed as percentage of the solvent-only control. $\mathrm{EC}_{50}$ values for each compound were calculated, from three independent replicate experiments, using 2 -fold dilution intervals.

\section{ASSOCIATED CONTENT}

\section{Supporting Information}

The Supporting Information is available free of charge at https://pubs.acs.org/doi/10.1021/acs.jnatprod.1c00811.

NMR, MS, ORD, UV, and IR data for the isolated compounds (PDF)

X-ray crystallographic data of compound 6 (CIF)

\section{AUTHOR INFORMATION}

\section{Corresponding Authors}

Stephen S. Nyandoro - Chemistry Department, College of Natural and Applied Sciences, University of Dar es Salaam, Dar es Salaam, Tanzania; Phone: +255-754-206560;

Email: nyandoro@udsm.ac.tz

Máté Erdélyi - Department of Chemistry-BMC, Uppsala University, SE-751 23 Uppsala, Sweden; 이이.orid.o0000003-0359-5970; Phone: +46-72-9999166;

Email: mate.erdelyi@kemi.uu.se

\section{Authors}

Gasper Maeda - Chemistry Department, College of Natural and Applied Sciences, University of Dar es Salaam, Dar es Salaam, Tanzania; Department of Chemistry-BMC, Uppsala University, SE-751 23 Uppsala, Sweden

Pieter J. Gilissen - Institute for Molecules and Materials, Radboud University, 6525 AJ Nijmegen, The Netherlands

Anastasia Rudenko - Department of Chemistry and Molecular Biology, Centre for Antibiotic Resistance Research (CARe) at the University of Gothenburg, SE-405 30 Gothenburg, Sweden; (1) orcid.org/0000-0002-8868-1204

Jelle van der Wal - Department of Chemistry and Molecular Biology, Centre for Antibiotic Resistance Research (CARe) at 
the University of Gothenburg, SE-405 30 Gothenburg, Sweden

Catarina Bourgard - Department of Chemistry and Molecular Biology, Centre for Antibiotic Resistance Research (CARe) at the University of Gothenburg, SE-405 30 Gothenburg, Sweden

Arvind Kumar Gupta - Department of Chemistry-Ångström, Uppsala University, SE-751 20 Uppsala, Sweden; (1) orcid.org/0000-0002-8969-1236

Per Sunnerhagen - Department of Chemistry and Molecular Biology, Centre for Antibiotic Resistance Research (CARe) at the University of Gothenburg, SE-405 30 Gothenburg, Sweden; (1) orcid.org/0000-0002-0967-8729

Joan J. E. Munissi - Chemistry Department, College of Natural and Applied Sciences, University of Dar es Salaam, Dar es Salaam, Tanzania

Complete contact information is available at:

https://pubs.acs.org/10.1021/acs.jnatprod.1c00811

\section{Notes}

The authors declare no competing financial interest.

The original NMR FIDs for all compounds are freely available on Zenodo as DOI: 10.5281 /zenodo.5275307.

\section{ACKNOWLEDGMENTS}

The Swedish Research Council (grants 2016-05857 and 201903715) and the Centre for Antibiotic Resistance Research (CARe) are acknowledged for financial support. This study made use of the NMR Uppsala infrastructure, which is funded by the Department of Chemistry-BMC and the Disciplinary Domain of Medicine and Pharmacy. We thank the University of Dar es Salaam for logistical support, and Mr. Frank M. Mbago, curator at the Herbarium of the Department of Botany, University of Dar es Salaam, for locating and identifying the plant species investigated.

\section{REFERENCES}

(1) "Uvaria L." Plants of the World Online; Royal Botanic Gardens: Kew, UK,http://www.plantsoftheworldonline.org/taxon/urn:lsid:ipni. org:names:30043123-2 (accessed Nov 5, 2021).

(2) Couvreur, T. L.; Helmstetter, A. J.; Koenen, E. J.; Bethune, K.; Brandão, R. D.; Little, S. A.; Sauquet, H.; Erkens, R. H. Front. Plant Sci. 2019, 9, 1941.

(3) Lasswell, W. L., Jr.; Hufford, C. D. J. Org. Chem. 1977, 42, $1295-1302$

(4) Xu, Q. M.; Zou, Z. M.; Xu, L. Z.; Yang, S. L. Chin. Chem. Lett. 2005, 16, 1343-1346.

(5) Takeuchi, Y.; Shi, Q.-W.; Sugiyama, T.; Oritani, T. Biosci., Biotechnol., Biochem. 2002, 66, 537-542.

(6) Nkunya, M. H.; Weenen, H.; Koyi, N. J.; Thijs, L.; Zwanenburg, B. Phytochemistry 1987, 26, 2563-2565.

(7) Kodpinid, M.; Sadavongvivad, C.; Thebtaranonth, C.; Thebtaranonth, Y. Tetrahedron Lett. 1983, 24, 2019-2022.

(8) Lekphrom, R.; Kanokmedhakul, K.; Schevenels, F.; Kanokmedhakul, S. Fitoterapia 2018, 127, 420-424.

(9) Auranwiwat, C.; Wongsomboon, P.; Thaima, T.; Rattanajak, R.; Kamchonwongpaisan, S.; Willis, A. C.; Laphookhieo, S.; Pyne, S. G.; Limtharakul, T. J. Nat. Prod. 2019, 82, 101-110.

(10) Starks, C. M.; Williams, R. B.; Rice, S. M.; Norman, V. L.; Lawrence, J. A.; Goering, M. G.; O’Neil-Johnson, M.; Hu, J.-F.; Eldridge, G. R. Phytochemistry 2012, 74, 185-189.

(11) Maeda, G.; van der Wal, J.; Gupta, A. K.; Munissi, J. J.; Orthaber, A.; Sunnerhagen, P.; Nyandoro, S. S.; Erdélyi, M. J. Nat. Prod. 2020, 83, 210-215.
(12) Wirasathien, L.; Pengsuparp, T.; Moriyasu, M.; Kawanishi, K.; Suttisri, R. Arch. Pharmacal Res. 2006, 29, 497-502.

(13) Nyandoro, S. S.; Munissi, J. J.; Gruhonjic, A.; Duffy, S.; Pan, F.; Puttreddy, R.; Holleran, J. P.; Fitzpatrick, P. A.; Pelletier, J.; Avery, V. M. J. Nat. Prod. 2017, 80, 114-125.

(14) Jolad, S. D.; Hoffmann, J. J.; Cole, J. R.; Tempesta, M. S.; Bates, R. B. Phytochemistry 1984, 23, 935-936.

(15) Stevenson, P. C.; Veitch, N. C.; Simmonds, M. S. Phytochemistry 2007, 68, 1579-1586.

(16) Lallo, S.; Lee, S.; Dibwe, D. F.; Tezuka, Y.; Morita, H. Nat. Prod. Res. 2014, 28, 1754-1759.

(17) Singh, J.; Dhar, K.; Atal, C. Tetrahedron 1970, 26, 4403-4406.

(18) Joshi, B.; Gawad, D.; Fuhrer, H. Tetrahedron Lett. 1979, 20, 2427-2430.

(19) Lange, G. L.; Organ, M. G.; Ruangrungsi, N.; Prathanturarug, S. Phytochemistry 1992, 31, 2397-2400.

(20) Taneja, S.; Koul, S.; Pushpangadan, P.; Dhar, K.; Daniewski, W.; Schilf, W. Phytochemistry 1991, 30, 871-874.

(21) Kupchan, S. M.; Hemingway, R. J.; Smith, R. M. J. Org. Chem. 1969, 34, 3898-3902.

(22) Liu, A.; Xu, L.; Zou, Z. Zhongguo Zhongyao Zazhi 2009, 34, $567-570$.

(23) Zhou, G.-X.; Zhang, Y.-J.; Chen, R.-Y.; Yu, D.-Q. J. Asian Nat. Prod. Res. 2010, 12, 696-701.

(24) Pan, X.-P.; Chen, R.-Y.; Yu, D.-Q. Phytochemistry 1998, 47, $1063-1066$.

(25) Yong-Hong, L.; Xu, L.-Z.; Yang, S.-L.; Dai, J.; Zhen, Y.-S.; Zhu, M.; Sun, N.-J. Phytochemistry 1997, 45, 729-732.

(26) Schulte, G. R.; Ganem, B.; Chantrapromma, K.; Kodpinid, M.; Kobkull, S. Tetrahedron Lett. 1982, 23, 289-292.

(27) Jaipetch, T.; Hongthong, S.; Kuhakarn, C.; Pailee, P.; Piyachaturawat, P.; Suksen, K.; Kongsaeree, P.; Prabpai, S.; Nuntasaen, N.; Reutrakul, V. Fitoterapia 2019, 137, 104182.

(28) Hollands, R.; Becher, D.; Gaudemer, A.; Polonsky, J. Tetrahedron 1968, 24, 1633-1650.

(29) Liang, G.-Y.; Gray, A. I.; Thomas, D. W.; Waterman, P. G. Phytochemistry 1988, 27, 3857-3860.

(30) Kijjoa, A.; Bessa, J.; Pinto, M. M.; Anatachoke, C.; Silva, A. M.; Eaton, G.; Herz, W. Phytochemistry 2002, 59, 543-549.

(31) Hongthong, S.; Kuhakarn, C.; Jaipetch, T.; Prabpai, S.; Kongsaeree, P.; Piyachaturawat, P.; Jariyawat, S.; Suksen, K.; Limthongkul, J.; Panthong, A. Fitoterapia 2015, 106, 158-166.

(32) Samwel, S.; Mdachi, S. J.; Nkunya, M. H.; Irungu, B. N.; Moshi, M. J.; Moulton, B.; Luisi, B. S. Nat. Prod. Commun. 2007, 2, 737-741.

(33) Liu, Y.-P.; Tang, J.-Y.; Hua, Y.; Lai, L.; Luo, X.-L.; Zhang, Z.-J.; Yin, W.-Q.; Chen, G.-Y.; Fu, Y.-H. Bioorg. Chem. 2018, 76, 386-391.

(34) Tang, J.-Y.; Liu, Y.-P.; Ju, P.-K.; Luo, X.-L.; Zhang, Z.-J.; Ren, P.; Lai, L.; Chen, G.-Y.; Fu, Y.-H. Nat. Prod. Res. 2018, 32, 17271732.

(35) Jolad, S. D.; Hoffmann, J. J.; Schram, K. H.; Cole, J. R.; Tempesta, M. S.; Bates, R. B. J. Org. Chem. 1981, 46, 4267-4272.

(36) Nkunya, M. H.; Weenen, H. Phytochemistry 1989, 28, 22172218.

(37) Iranpoor, N.; Firouzabadi, H.; Khalili, D. Org. Biomol. Chem. 2010, 8, 4436-4443.

(38) Jain, P.; Bari, S. Asian J. Plant Sci. 2010, 9, 163-167.

(39) Joshi, H.; Saxena, G. K.; Singh, V.; Arya, E.; Singh, R. P. J. Pharmacogn. Phytochem. 2013, 2, 145-151.

(40) Koudokpon, H.; Armstrong, N.; Dougnon, T. V.; Fah, L.; Hounsa, E.; Bankole, H. S.; Loko, F.; Chabriere, E.; Rolain, J. M. BioMed Res. Int. 2018, 2018, 10.

(41) Nkunya, M. H. H. Pure Appl. Chem. 2005, 77, 1943-1955.

(42) Zandi, L.; Makungu, M.; Munissi, J. J. E.; Duffy, S.; Puttreddy, R.; von der Heiden, D.; Rissanen, K.; Avery, V. M.; Nyandoro, S. S.; Erdelyi, M. J. Nat. Prod. 2020, 83, 2641-2646.

(43) Wang, S.; Chen, R.-Y.; Yu, S.-S.; Yu, D.-Q. J. Asian Nat. Prod. Res. 2003, 5, 17-23.

(44) Wang, S.; Zhang, P.-C.; Chen, R.-Y.; Dai, S.-J.; Yu, S.-S.; Yu, D.Q. J. Asian Nat. Prod. Res. 2005, 7, 687-694. 
(45) Zhou, G.-X.; Chen, R.-Y.; Yu, D.-Q. J. Asian Nat. Prod. Res. 1999, 1, 227-238.

(46) Parimita, S. P.; Ramshankar, Y. V.; Suresh, S.; Guru Row, T. N. Acta Crystallogr., Sect. E: Struct. Rep. Online 2007, 63, No. o860-o862. (47) Sheldrick, G. M. Acta Crystallogr., Sect. A: Found. Crystallogr. 2008, A64, 112-122.

(48) Dolomanov, O. V.; Bourhis, L. J.; Gildea, R. J.; Howard, J. A. K.; Puschmann, H. J. Appl. Crystallogr. 2009, 42, 339-341.

(49) Sheldrick, G. M. Acta Crystallogr., Sect. A: Found. Adv. 2015, 71, $3-8$.

(50) Sheldrick, G. M. Acta Crystallogr., Sect. C: Struct. Chem. 2015, $71,3-8$.

(51) Hooft, R. W.; Straver, L. H.; Spek, A. L. J. Appl. Crystallogr. 2008, 41, 96-103.

(52) Flack, H. Acta Crystallogr., Sect. A: Found. Crystallogr. 1983, 39, 876-881.

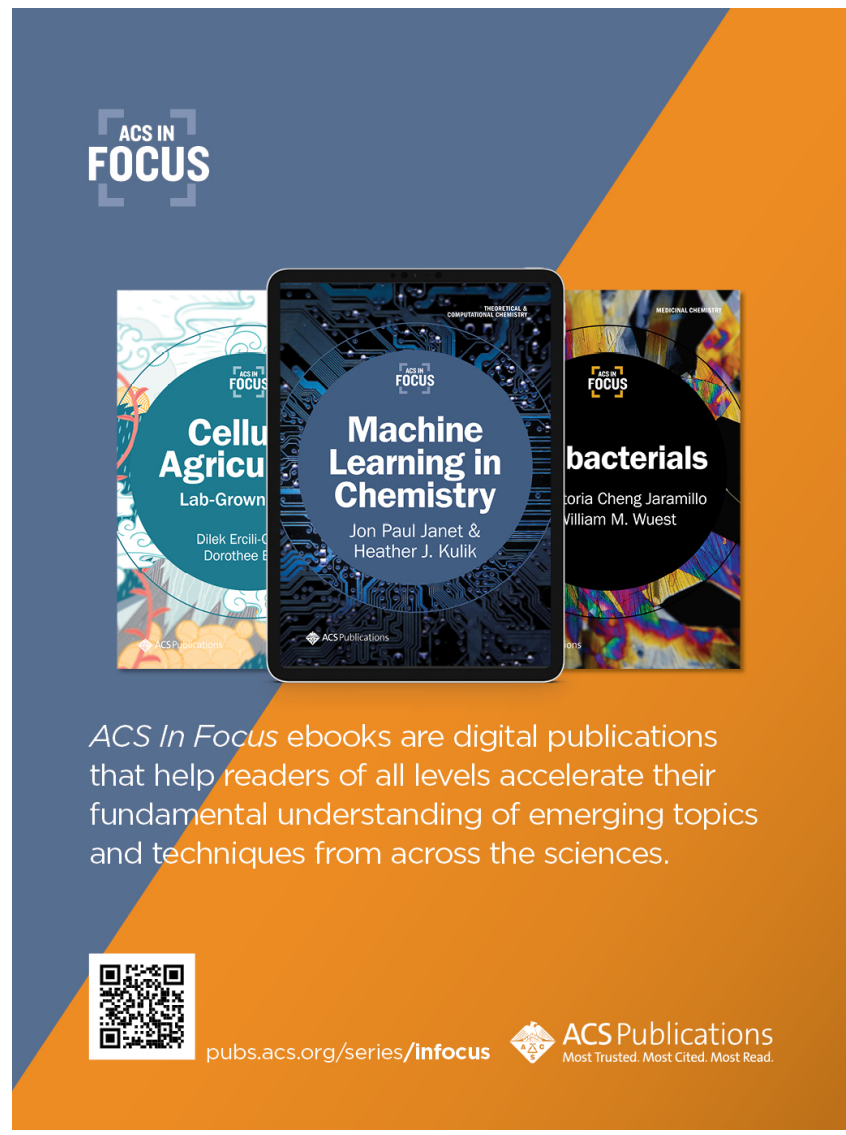

